Article

\title{
Spatial and Temporal Variability of Soil Redox Potential, pH and Electrical Conductivity across a Toposequence in the Savanna of West Africa
}

\author{
Bernard F. Tano ${ }^{1, *}$, Casimir Y. Brou ${ }^{1}$, Elliott R. Dossou-Yovo ${ }^{2}$, Kazuki Saito $^{2},{ }$ Koichi Futakuchi ${ }^{2}$, \\ Marco. C. S. Wopereis ${ }^{3}$ and Olivier Husson $2,4,5$ (D) \\ 1 Unité Mixte de Recherche et d'Innovation (UMRI), Science Agronomique et Génie Rural, Département de \\ Formation et de Recherche Agriculture et Ressources Animales, Institut National Polytechnique Félix \\ Houphouët Boigny (INP-HB), Yamoussoukro BP 1313, Côte d'Ivoire; ycasimir.brou@gmail.com \\ 2 Africa Rice Center, Bouake 01 BP 2551, Côte d'Ivoire; e.dossou-yovo@cgiar.org (E.R.D.-Y.); \\ k.saito@cgiar.org (K.S.); k.futakuchi@cgiar.org (K.F.); olivier.husson@cirad.fr (O.H.) \\ 3 World Vegable Center (WorldVeg), P.O. Boîte 42, Shanhua, Tainan 74199, Taiwan; \\ marco.wopereis@worldveg.org \\ 4 Centre de Coopération Internationale en Recherche Agronomique pour le Développement (CIRAD), \\ Unité Propre de Recherche Agroécologie et Intensification Durable des cultures Annuelles (UPR AIDA), \\ F-34398 Montpellier, France \\ 5 Agroécologie et Intensification Durable des cultures Annuelles (AIDA), Univ. Montpellier, Centre de \\ Coopération Internationale en Recherche Agronomique pour le Développement (CIRAD), \\ F-34398 Montpellier, France \\ * Correspondence: firmintano@yahoo.fr
}

Received: 21 October 2020; Accepted: 12 November 2020; Published: 15 November 2020

\begin{abstract}
Soil redox potential is an important factor affecting soil functioning. Yet, very few agronomy studies included soil redox potential in relation to soil processes. The objective of this study was to evaluate the spatial and temporal variation in soil redox potential and to determine the soil parameters affecting its variation. Soil redox potential, soil moisture, soil temperature, $\mathrm{pH}$ and bulk electrical conductivity were measured in upland rice fields during two growing seasons at six positions along an upland-lowland continuum, including two positions at the upland, two at the fringe and two at the lowlands in central Côte d'Ivoire (West Africa). The measurements were made at the following soil depths: $3,8,20$ and $35 \mathrm{~cm}$. Soil redox potential varied between 500 and $700 \mathrm{mV}$ at the upland positions, 400 and $700 \mathrm{mV}$ at the fringe positions and 100 and $750 \mathrm{mV}$ at the lowland positions, and increased with soil depth. Variations in soil redox potential were driven by soil moisture, bulk electrical conductivity and soil organic carbon. We concluded that for proper interpretation of soil redox potential, sampling protocols should systematically include soil $\mathrm{pH}$, moisture and bulk electrical conductivity measurements.
\end{abstract}

Keywords: ecologies; electrochemical parameters; $\mathrm{pH}$; redox potential; relationships; soil moisture; variation

\section{Introduction}

Declining soil fertility is a major impediment to agricultural productivity and the main cause of low food production in sub-Saharan Africa [1]. This is the result of poorly adapted production systems such as slash-and-burn farming and too short fallow periods, leading to a continuous degradation of the productive capacity of the land [2-4].

In a context of innovation for sustainable agriculture, there is an urgent need to implement agricultural practices that take into account the processes at stake in soil functioning and are able to 
maintain and reinforce soil fertility [5]. This suggests working with effective indicators to understand soil processes to design appropriate cropping systems. Indeed, the dynamics of key indicators and their critical limits are needed to track changes and determine the trends in soil quality improvement or deterioration for various agro-ecological zones [6,7].

Thus, various relevant soil parameters are regularly monitored: $\mathrm{pH}$, a major parameter in many physical-chemical reactions, influences the solubility and bioavailability of many soil minerals [8-10]. Electrical conductivity $(\mathrm{EC})$ is also widely used to characterize various soil properties, such as cation exchange capacity, salinity, nutrient concentration, residual moisture and soil texture $[7,11,12]$. We can now associate the redox potential (Eh) to the level of oxidation/reduction in a given environment, with soil redox potential values lower than $400 \mathrm{mV}$ indicating a reduced environment. This important parameter, which has long been neglected by agronomists because of the great variability in the measurements $[5,13,14]$, is now accessible after the robustness of the proposed measurement methods [15].

Oxidation-reduction reactions have a profound effect on soil evolution. The chemical evolution of soils is mainly determined by proton and electron fluxes that define the predominant soil mineral fields $[16,17]$ and their solubility [18]. In addition, Eh influences greenhouse gas emissions. Indeed, the processes of decomposition, nitrification, denitrification or methanogenesis, respectively producing carbon dioxide $\left(\mathrm{CO}_{2}\right)$, nitrous oxide $\left(\mathrm{N}_{2} \mathrm{O}\right)$ or methane $\left(\mathrm{CH}_{4}\right)$, are typical reductive oxidative reactions that occur through electron exchange between the substrates [19-21]. Furthermore, soil Eh (and pH) largely impacts the vegetation type, and inversely, plants alter soil Eh (and $\mathrm{pH}$ ), especially in the rhizosphere [5], making the plant essential in the course of the physicochemical processes in the soil.

Thus, with $\mathrm{pH}$, Eh can therefore provide essential information for characterizing soil conditions and its environment. Eh measurements could be used as a key indicator of field processes [5].

In soil the different parameters interact, therefore, soil processes can be better understood when a combination of these relevant parameters is used. However, to do so, there is a need to better understand the spatial and temporal variability of these indicators at the field scale, in order to develop sampling protocols enabling a good control of this variability. Such an approach is an innovation in the West African region.

The objective of this study was therefore to assess the spatial and temporal variation in soil redox potential, $\mathrm{pH}$ and $\mathrm{EC}$, and the soil parameters driving their variability in a derived savanna agro-ecological zone of West Africa.

\section{Materials and Methods}

\subsection{Study Area}

The study was conducted in rainfed rice fields during two consecutive growing seasons, from June to November 2016 and from June to November 2017, on two close experimental sites at the Africa Rice Center research station M'bé located in the center of Ivory Coast. The station is located $35 \mathrm{~km}$ north of Bouaké, between $7.5^{\circ}$ and $8.5^{\circ}$ North latitude and $4.5^{\circ}$ and $5.5^{\circ}$ West longitude (Figure 1).

The station is located in the agro-ecological zone of a derived savanna, mainly characterized by a bi-modal rainfall pattern with two rainy seasons and two dry seasons. The first rainy season lasts from March to June and the second rainy season from September to October [22]. Based on the climate data for the period 1994-2014, the average annual rainfall is $1150 \mathrm{~mm}$. Two peaks of rainfall are observed in the study area: the first in June, with a total monthly rainfall amount of $125 \mathrm{~mm}$, and the second in September or October, with a total rainfall amount of $140 \mathrm{~mm}$. The average daily temperatures vary between $30^{\circ} \mathrm{C}$ in March and $21^{\circ} \mathrm{C}$ in January.

The measurements were made at six row positions along an upland-lowland continuum, including two positions at the upland (Site 1), two at the fringe and two at the lowlands (Site 2). The upland positions (Upland 1 and Upland 2) and the lowland positions (valley bottom) had a relatively gentle 
slope $(<1 \%$ and $2 \%$, respectively) while the fringe and glacis positions had a relatively higher slope, $5 \%$ on average (Figure 2 ).

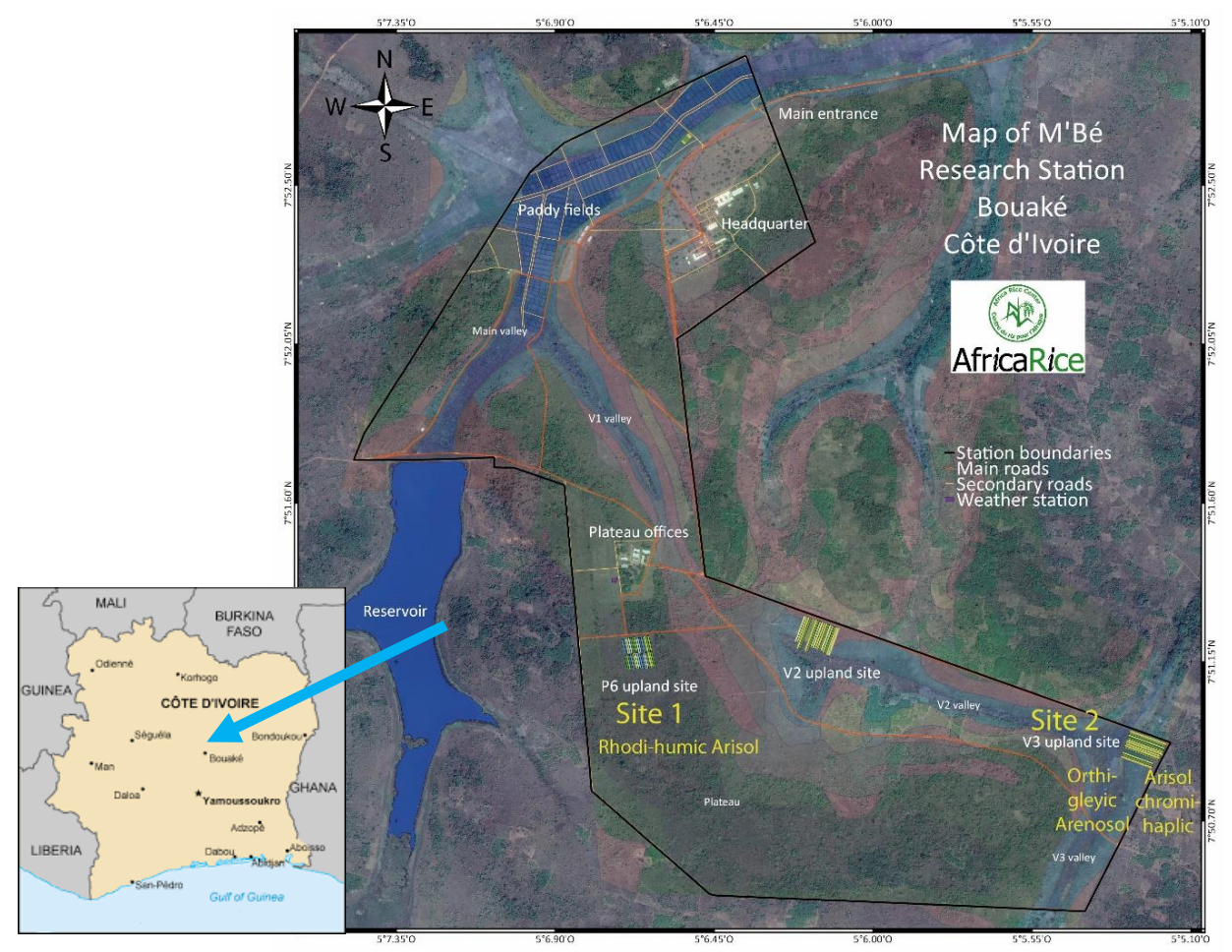

Figure 1. Location of the experimental site.

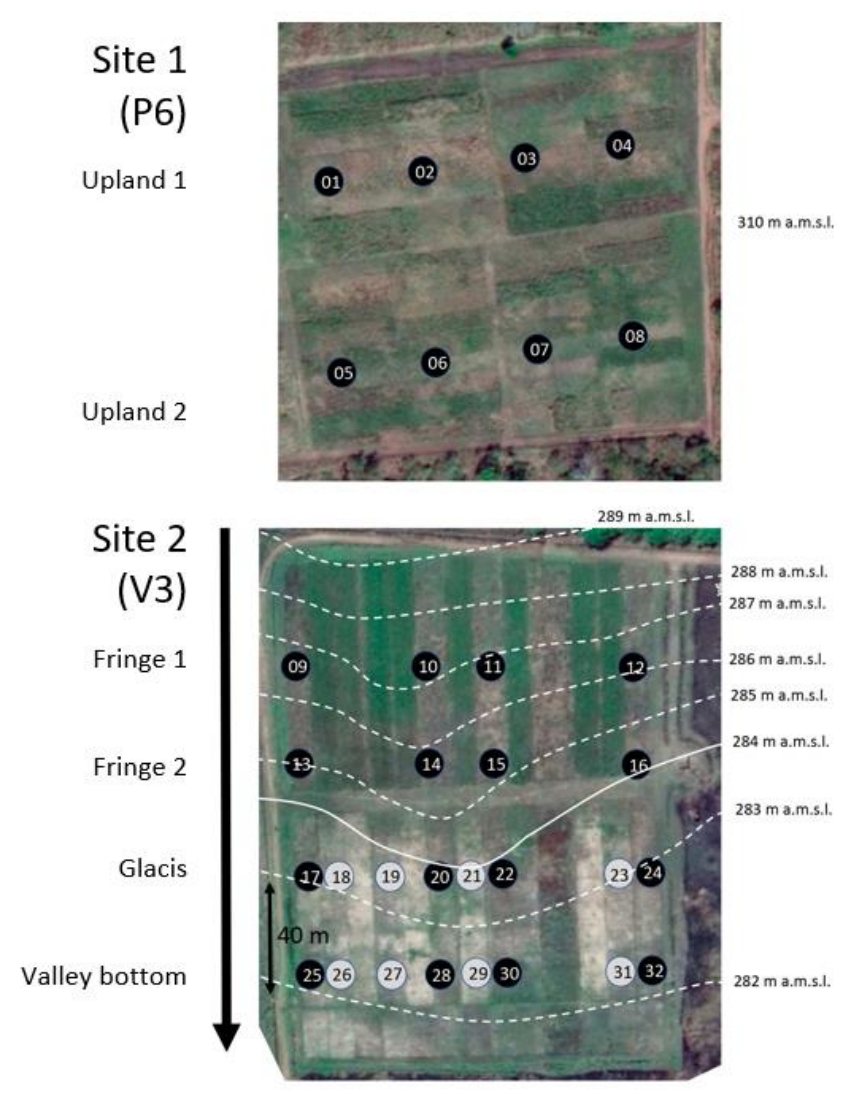

Figure 2. Sampling points and measurements. 
According to the FAO soil taxonomy, soil at the upland was a Rhodi-humic Arisol; soil along the slope was an Arisol chromi-haplic and soil at the lowland was an Orthi-gleyic Arenosol [22]. Soils of the two sites were characterized before the beginning of the experiment through soil profiles (Figure 3).

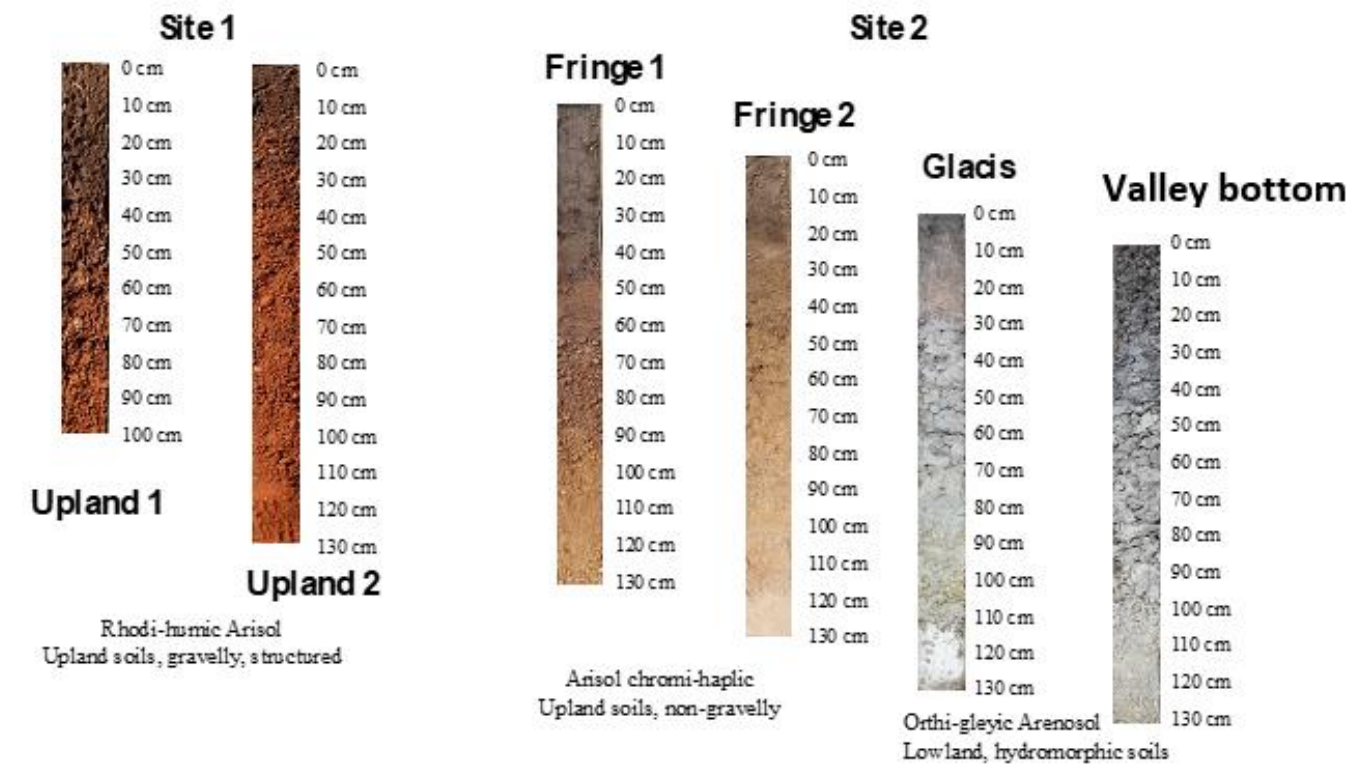

Figure 3. Profiles of the soils at the experimental sites.

At each experimental site, soil samples were collected at three soil depths: $0-5 \mathrm{~cm}, 15-25 \mathrm{~cm}$ and $35-45 \mathrm{~cm}$. Soil samples (approximately $250 \mathrm{~g}$ ) were air-dried at $30-35^{\circ} \mathrm{C}$ to reach a water activity close to 0.5 , measured with a HP23-AW-SET-14 Rotronic water activity device (PST Group, Bassersdorf, Switzerland) as described in [15]. The physicochemical analyzes were carried out on the fine soil sieved to $2 \mathrm{~mm}$. Organic carbon was measured by the Walkley and Black method by oxidation of the organic material with a mixture of sulfuric acid $\left(\mathrm{H}_{2} \mathrm{SO}_{4}\right)$ and potassium dichromate $\left(\mathrm{K}_{2} \mathrm{Cr}_{2} \mathrm{O}_{7}\right)$ and titration of the remaining amount of $\mathrm{K}_{2} \mathrm{Cr}_{2} \mathrm{O}_{7}$ with ferrous sulphate. Granulometric analyzes were performed by sieving and pipetting according to the Robinson pipette method, oxidation of the organic material with hydrogen peroxide $\left(\mathrm{H}_{2} \mathrm{O}_{2}\right)$, then dispersion with a solution of sodium hexametaphosphate $\left(\mathrm{NaPO}_{3}\right)_{6}$ and finally pipetting for the particles [23].

The $\mathrm{pH}$ measurements in water $\left(\mathrm{pH}-\mathrm{H}_{2} \mathrm{O}\right)$ were made by extraction with distilled water taking a solid/liquid mass ratio of 1 to 2.5 followed by a reading with a $3520 \mathrm{pH}$ meter (Jenway, Stone, UK). Similarly, the electrical conductivity measurement was carried out in distilled water with a ratio of 1 to 2.5 and reading the conductivity.

Analysis of soil particle size distribution (Table 1) revealed a unique texture on Upland 1 (Site 1): sandy clay loam at horizons $0-5 \mathrm{~cm}, 15-25 \mathrm{~cm}$ and $35-45 \mathrm{~cm}$. On Upland 2, the texture varied from sandy loam in the $0-5 \mathrm{~cm}$ horizon to sandy clay loam in the horizons $15-25 \mathrm{~cm}$ and $35-45 \mathrm{~cm}$. At Site 2, two textural situations were present on Fringe 1: loamy sand in the horizons $0-5 \mathrm{~cm}$ and $15-25 \mathrm{~cm}$ and sandy clay loam in horizon $35-45 \mathrm{~cm}$. A unique texture was observed on Fringe 2: loamy sand in horizons $0-5 \mathrm{~cm}, 15-25 \mathrm{~cm}$ and $35-45 \mathrm{~cm}$. On glacis, two textural situations were observed: sandy clay loam in horizons $0-5 \mathrm{~cm}$ and $15-25 \mathrm{~cm}$ and loamy sand in the horizon $35-45 \mathrm{~cm}$. In the valley bottom, two textural situations also were observed: sandy clay loam in horizons $0-5 \mathrm{~cm}$ and $15-25 \mathrm{~cm}$ and clay loam in horizon $35-45 \mathrm{~cm}$. 
Table 1. Mean values $(n=4)$ of the soil characteristics at different depths at the experimental sites. Detailed values showing their spatial variability are given in Figure S1 in the Supplementary Material.

\begin{tabular}{|c|c|c|c|c|c|c|c|c|}
\hline & $\begin{array}{c}\text { Soil } \\
\text { Depth }\end{array}$ & $\underset{\left(\mathbf{H}_{2} \mathbf{0}\right)}{\mathrm{pH}}$ & $\begin{array}{l}\text { Organic } \\
\text { Carbon } \\
(\%)\end{array}$ & $\begin{array}{c}\text { Electrical } \\
\text { Conductivity } \\
(\mu \mathrm{S} / \mathrm{cm})\end{array}$ & $\begin{array}{l}\text { Clay } \\
(\%)\end{array}$ & $\begin{array}{l}\text { Silt } \\
(\%)\end{array}$ & $\begin{array}{c}\text { Sand } \\
(\%)\end{array}$ & Texture \\
\hline \multirow{3}{*}{ Upland 1} & $0-5 \mathrm{~cm}$ & 6.48 & 3.45 & 119.0 & 23.25 & 17.75 & 59.0 & Sandy clay loam \\
\hline & $15-25 \mathrm{~cm}$ & 6.70 & 2.41 & 54.1 & 28.25 & 12.25 & 59.5 & Sandy clay loam \\
\hline & $35-45 \mathrm{~cm}$ & 6.70 & 1.37 & 47.3 & 31.46 & 10.50 & 58.0 & Sandy clay loam \\
\hline \multirow{3}{*}{ Upland 2} & $0-5 \mathrm{~cm}$ & 6.27 & 2.62 & 86.4 & 16.21 & 11.25 & 72.5 & Sandy loam \\
\hline & $15-25 \mathrm{~cm}$ & 6.40 & 1.43 & 32.2 & 26.00 & 8.74 & 65.3 & Sandy clay loam \\
\hline & $35-45 \mathrm{~cm}$ & 6.31 & 1.03 & 28.6 & 30.77 & 8.22 & 61.0 & Sandy clay loam \\
\hline \multirow{3}{*}{ Fringe 1} & $0-5 \mathrm{~cm}$ & 6.59 & 2.15 & 89.4 & 12.00 & 7.50 & 80.5 & Loamy sand \\
\hline & $15-25 \mathrm{~cm}$ & 6.59 & 1.43 & 61.0 & 17.50 & 7.00 & 75.5 & Loamy sand \\
\hline & $35-45 \mathrm{~cm}$ & 6.61 & 1.05 & 55.3 & 24.00 & 6.50 & 69.5 & Sandy clay loam \\
\hline \multirow{3}{*}{ Fringe 2} & $0-5 \mathrm{~cm}$ & 6.57 & 1.75 & 84.4 & 5.93 & 7.50 & 86.5 & Loamy sand \\
\hline & $15-25 \mathrm{~cm}$ & 6.76 & 0.92 & 35.9 & 6.50 & 6.85 & 86.7 & Loamy sand \\
\hline & $35-45 \mathrm{~cm}$ & 6.74 & 0.56 & 43.2 & 6.32 & 7.00 & 86.7 & Loamy sand \\
\hline \multirow{3}{*}{ Glacis } & $0-5 \mathrm{~cm}$ & 6.24 & 2.92 & 143.3 & 22.25 & 16.25 & 61.5 & Sandy clay loam \\
\hline & $15-25 \mathrm{~cm}$ & 6.56 & 1.20 & 54.5 & 23.50 & 11.50 & 65.0 & Sandy clay loam \\
\hline & $35-45 \mathrm{~cm}$ & 6.47 & 0.32 & 34.0 & 14.00 & 6.50 & 79.5 & Loamy sand \\
\hline \multirow{3}{*}{$\begin{array}{l}\text { Valley } \\
\text { bottom }\end{array}$} & $0-5 \mathrm{~cm}$ & 6.32 & 3.56 & 189.2 & 22.00 & 24.25 & 53.8 & Sandy clay loam \\
\hline & $15-25 \mathrm{~cm}$ & 6.78 & 1.20 & 92.8 & 28.67 & 18.33 & 53.0 & Sandy clay loam \\
\hline & $35-45 \mathrm{~cm}$ & 6.93 & 0.63 & 114.5 & 37.00 & 18.75 & 44.3 & Clay loam \\
\hline
\end{tabular}

All the experimental sites were slightly acidic (6.24-6.93). Soil organic carbon and electrical conductivity decreased with soil depth (Table 1).

\subsection{Experimental Design}

The experiments were conducted at 2 sites located along the upland-lowland continuum. Both sites were reclaimed in 2015, after over 12 years of being fallow but with frequent burning by wildfires. On Site 1, the upper part of the toposequence located on the plateau, the vegetation before reclamation consisted of tall (up to $4 \mathrm{~m}$ high) perennial grasses dominated by Pennisetum purpureum Schumach., Andropogon gayanus Kunth and Hyparrhenia rufa (Nees) Stapf, mixed with other species such as Digitaria horizontalis Willd., Mucuna pruriens (L.) DC., Aeschynomene histrix Poir., 1816, Tridax procumbens L. or Spermacoce stachydea DC. The vegetation on Site 2 showed a strong gradient across the toposequence: the vegetation of the sandy-loamy fringe was largely dominated by Imperata cylindrica (L.) Raeusch, with ocally a few species such as Hyparrhenia involucrata Stapf or Digitaria horizontalis Willd. In between, on the "glacis", the vegetation consisted of a diverse mixture of Imperata cylindrica (L.) Raeusch., Leersia hexandra Sw., Cyperus spp. (especially C. ferrax and C. esculentus), Centrosema spp., Phyllanthus amarus Schumach. E Thonn., Aspilia bussei bussei O. Hoffm. \& Muschl, Eclipta prostrata (L.) L., etc. In the "bas-fond", the lowest part of the toposequence, the vegetation was largely dominated by Leersia hexandra $S w$.

Land reclamation started in 2015, with the destruction of perennial grasses through crushing and application of herbicide (glyphosate $1800 \mathrm{~g} \mathrm{ha}^{-1}$ ) once re-growing plants were $30 \mathrm{~cm}$ tall. Rice was then cultivated for the first time after ploughing and harrowing, and sawn in June 2015. During the two consecutive growing seasons (June-November 2016 and June-November 2017), land at each experimental site was firstly plowed to a depth of $30 \mathrm{~cm}$ in March and secondly plowed to a depth of $30 \mathrm{~cm}$ in May to remove all weeds and properly harrow the field. A rice variety able to grow in a wide range of hydrological conditions was selected as the crop in this study. The upland rice variety NERICA 4, with a broad adaptation range [24], was grown; it was planted in pods at a $0.3 \mathrm{~m} \times 0.3 \mathrm{~m}$ spacing-5 to 8 grains per pod-with a basal fertilizer application of $200 \mathrm{~kg}$ ha-1 of NPK (12-24-18), equivalent to 
$24 \mathrm{~kg} \mathrm{~N} \mathrm{ha}^{-1}, 48 \mathrm{~kg} \mathrm{P} \mathrm{ha}^{-1}$ and $36 \mathrm{~kg} \mathrm{~K} \mathrm{ha}^{-1}$, a first top-dressing fertilizer (urea at $87 \mathrm{~kg} \mathrm{ha}^{-1}$ at 30 days after sowing (DAS)) and a second-top dressing fertilizer (urea at $87 \mathrm{~kg} \mathrm{ha}^{-1}$ at $60 \mathrm{DAS}$ ). Seeds were treated against fungi and insects and herbicide (oxadiazon, $1000 \mathrm{~g} \mathrm{ha}^{-1}$ ) at sowing. No pesticide was applied afterwards. The experimental design was a randomized complete block with 4 replicates.

\subsection{Measurement of Electrochemical Soil Parameters}

\subsubsection{Measurement of Soil Redox Potential (Eh)}

Soil redox potential was measured following [15], with a WTW3110 voltmeter (WTW, Weilheim, Germany) (with an input resistance greater than $5 \times 10^{12} \mathrm{Ohm}$ ), an radiometer analytical $\mathrm{Ag} / \mathrm{AgCl}$ (KCL 3M) reference electrodes Ref 321 and a 40-cm-long, handmade probe produced by Paleoterra (Netherlands), made of tubes of $8 \mathrm{~mm}$ in diameter epoxy reinforced with fiberglass in which was integrated platinum $((\mathrm{Pt})$ pure redox sensors $(99.95 \%)$. The probe was connected to a cable filled and sealed with epoxy to form a sturdy and waterproof assembly that can be hammered into the ground. The Pt sensors were distributed on the probe to obtain measurements at depths of $3 \mathrm{~cm}, 8 \mathrm{~cm}, 20 \mathrm{~cm}$ and $35 \mathrm{~cm}$. Each Pt sensor was connected to its own wire inside the cable. Soil redox potential (Eh) was measured simultaneously on the different depths by connecting each Pt sensor to a different voltmeter and reference electrode.

Before each series of measurements, the electrodes were cleaned with very fine sand paper and calibrated regularly following [15]. The electrodes rinsed with distilled water were then calibrated in a $220 \mathrm{mV}$ Zobell buffer solution before being rinsed and recalibrated in a $220 \mathrm{mV}$ Zobell buffer diluted to $1 \%$ in $0.1 \mathrm{M} \mathrm{KCl}$. Finally, the electrodes were rinsed and wiped with paper and used for a series of 10 to 15 measurements.

The redox potential was measured by vertically planting the redox probe at the desired depth into the ground, using a hammer. The $\mathrm{Ag} / \mathrm{AgCl}$ reference electrodes associated with the different $\mathrm{Pt}$ sensors were gently inserted into the soil at $2-3 \mathrm{~cm}$ near the redox probe (radius $5-15 \mathrm{~cm}$ ). The E value for each depth was the $\mathrm{E}$ (in $\mathrm{mV}$ ), indicated on the voltmeter that was associated after $1 \mathrm{~min}$ with no change in the $\mathrm{E}$ unit. After being measured, according to the $\mathrm{Ag} / \mathrm{AgCl}$ reference electrode, all potentials vs. $\mathrm{AG} / \mathrm{AgCl}(\mathrm{E})$ were transformed to give Eh according to the normal hydrogen electrode (NHE) with the relationship between the $\mathrm{Ag} / \mathrm{AgCl}$ reference, temperature and $\mathrm{NHE}$ provided by the radiometer instrument.

The first measurement at the beginning of a series, after the electrode testing and cleaning, have always been considered as a "test" and were not included in the data analysis [15].

On the plots, measurements were collected as far as possible at a frequency of 15 days at each site, between 08:00 and 11:00 a.m. to account for the variability of redox due to changes in soil temperatures during the day. In case of rain, the measurements were suspended for 24 to $48 \mathrm{~h}$.

In order to better define the redox conditions of the soils studied, Eh can be adjusted to $\mathrm{pH}$ $7[15,25]$

$$
E h_{p h 7}=E h-\frac{R T}{F} \times \operatorname{Ln} 10 \times(7-p H)
$$

where $E h_{p H 7}$ is the soil redox potential at $\mathrm{pH}=7, R$ is the perfect gas constant $\left(8.314 \mathrm{JK}^{-1} \mathrm{~mol}^{-1}\right), T$ is the temperature in Kelvin $\left(25^{\circ} \mathrm{C}=298, \mathrm{~K}\right)$ and $F$ the Faraday constant $\left(96,485 \mathrm{C} \mathrm{mol}^{-1}=1 \mathrm{~F}\right)$. At $25^{\circ} \mathrm{C}$, $E h_{p H 7}=$ Eh-0.059 $\times(\mathrm{pH} 7)$.

In this study, we used the notion of pe $+\mathrm{pH}$, which is equivalent to $E h_{p H 7}$, as shown by [26] as

$$
E h_{p H 7}=\frac{R T}{F} \times \operatorname{Ln} 10 \times(p e+p H-7)
$$

or

$$
p e+p H=\frac{E h_{p H 7} \times F}{R T \times \operatorname{Ln} 10}+7
$$




\subsubsection{Measurement of Soil $\mathrm{pH}$ and Temperature}

The soil $\mathrm{pH}$ and temperature $\left({ }^{\circ} \mathrm{C}\right)$ were measured at depths of $3 \mathrm{~cm}, 8 \mathrm{~cm}, 20 \mathrm{~cm}$ and $35 \mathrm{~cm}$ with a Field Scout Soil Stick pH Meter (Spectrum Technologies Inc., Aurora, IL, USA), which is equipped with a flat surface electrode and simultaneously displays $\mathrm{pH}$ and temperature. Before each series of measurements, the $\mathrm{pH}$ meter soil stick was calibrated with $\mathrm{pH} 4$ and $\mathrm{pH} 7$ solutions. The $\mathrm{pH}$ meter was regularly cleaned with water between measurements.

\subsubsection{Measurement of Soil Humidity and Electrical Conductivity}

Volumetric soil moisture and bulk electrical conductivity $(\mathrm{Ecb})$ were measured at depths of $3 \mathrm{~cm}$, $8 \mathrm{~cm}, 20 \mathrm{~cm}$ and $35 \mathrm{~cm}$ with a portable HH2 moisture meter (Delta-T Ltd. device, Cambrigde, UK) and a portable WET-2 sensor (Delta-T Ltd. device, Cambrigde, UK).

\subsection{Statistical Analyses}

Statistical tests, models and figures were done with Statistica 7.1 and R software. An analysis of variance was conducted on the data collected. Mean values were tested for significant differences using a least significant difference (LSD) or standard error of difference (SED) test. The probability level of 0.05 was designated as significant. Correlation circles and multi-linear regression analyses were conducted to identify the associations and relationships between the soil redox potential and the soil properties at each experimental site and soil depth.

\section{Results}

\subsection{Rainfall and Air Temperature}

The cumulative rainfall amount was higher during the growing season (June-December) of 2017 (785 mm) than during the growing period (June-December) of $2016(540 \mathrm{~mm})$ (Figure 3). The rainfall amount was low at the beginning of the growing season in June $(45 \mathrm{~mm})$ and reached its peak in September with $178 \mathrm{~mm}$ and $215 \mathrm{~mm}$ in 2016 and 2017, respectively. The rainfall was more evenly distributed in 2017 than in 2016, with 57 rainfall events in 2017 compared with 51 rainfall events in 2016. During the growing season, the average daily air temperature slightly varied between 21 and $26^{\circ} \mathrm{C}$ in both years. At the experimental sites, there was a seasonal variation in the daily temperature with the lowest temperatures $\left(21-26^{\circ} \mathrm{C}\right)$ recorded during the period June-November and the highest temperatures $\left(30^{\circ} \mathrm{C}\right)$ recorded during the period March-May. The average daily temperature was about $25^{\circ} \mathrm{C}$ in 2016 and 2017 (Figure 4).

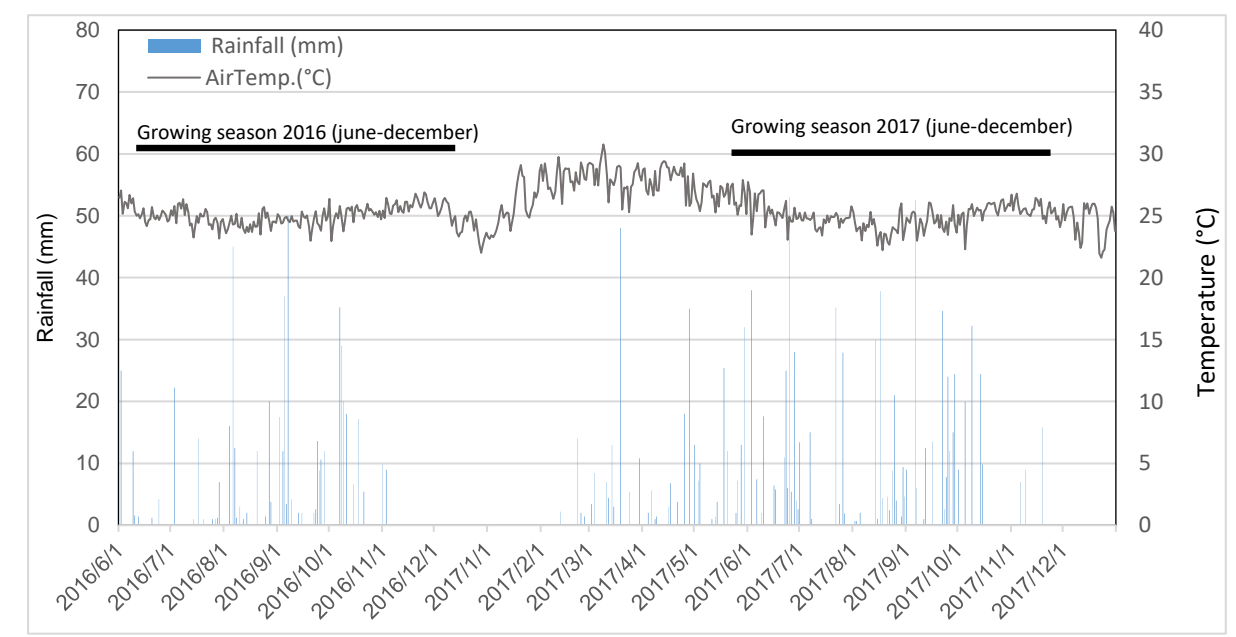

Figure 4. Daily rainfall (mm) and daily air average temperature $\left({ }^{\circ} \mathrm{C}\right)$ during the 2016 and 2017 crop seasons at the experimental station. 


\subsection{Soil Moisture}

The evolution of the soil moisture in the uplands (Upland 1 and Upland 2), fringes (Fringe 1 and Fringe 2) and lowlands (glacis and valley bottom) during the 2016 and 2017 growing seasons are shown in Figure 4. The average soil moisture was significantly higher in $2017\left(0.21 \mathrm{~m}^{3} \mathrm{~m}^{-3}\right)$ than in $2016\left(0.17 \mathrm{~m}^{3} \mathrm{~m}^{-3}\right)$ (Table 2). The mean soil moisture during the two growing seasons was significantly higher in the lowland ecology $\left(0.28 \mathrm{~m}^{3} \mathrm{~m}^{-3}\right.$ and $0.22 \mathrm{~m}^{3} \mathrm{~m}^{-3}$, respectively, for valley bottom and glacis) than on the uplands $\left(0.15 \mathrm{~m}^{3} \mathrm{~m}^{-3}\right.$ and $0.12 \mathrm{~m}^{3} \mathrm{~m}^{-3}$, respectively, for Upland 1 and Upland 2) and fringes $\left(0.11 \mathrm{~m}^{3} \mathrm{~m}^{-3}\right.$ and $0.08 \mathrm{~m}^{3} \mathrm{~m}^{-3}$, respectively, for Fringe 1 and Fringe 2). Soil moisture was higher in the deepest soil horizons than at the surface horizon (Table 2). Soil moisture also significantly varied within the growing season and fluctuated with the rainfall amount. In general, the soil moisture was higher in the months of September and October when the highest rainfall amount was recorded (Figure 5).

Table 2. Average soil electrochemical characteristics at different soil depths of the experimental sites.

\begin{tabular}{|c|c|c|c|c|c|c|}
\hline Treatments & Temperature $\left({ }^{\circ} \mathrm{C}\right)$ & $\mathrm{pH}$ & $\begin{array}{l}\text { Moisture } \\
\left(\mathrm{m}^{3} \cdot \mathrm{m}^{-3}\right)\end{array}$ & $\begin{array}{c}\mathrm{ECb} \\
\left(\mathrm{mS} . \mathrm{cm}^{-1}\right)\end{array}$ & Eh $(\mathrm{mV})$ & $\mathrm{Pe}+\mathrm{pH}$ \\
\hline \multicolumn{7}{|l|}{ Year $(\mathrm{Y})$} \\
\hline 2016 & $28.2^{\mathrm{a}}$ & $5.94^{a}$ & $0.17^{\mathrm{a}}$ & $0.14^{\mathrm{a}}$ & $560^{a}$ & $15.35^{\mathrm{a}}$ \\
\hline 2017 & $29.1^{b}$ & $5.99^{\mathrm{a}}$ & $0.21^{\mathrm{b}}$ & $0.18^{b}$ & $562^{a}$ & $15.34^{\mathrm{a}}$ \\
\hline SED (main year effect) & 0.1 & ns & 0.01 & 0.01 & ns & ns \\
\hline \multicolumn{7}{|l|}{ Site (S) } \\
\hline Upland 1 & $29.5^{c}$ & $6.40^{\mathrm{d}}$ & $0.15^{\mathrm{d}}$ & $0.09^{b}$ & $570^{b, c}$ & $15.90^{\mathrm{d}}$ \\
\hline Upland 2 & $28.2^{\mathrm{a}}$ & $5.90 \mathrm{~b}$ & $0.12^{\mathrm{c}}$ & $0.06^{a, b}$ & $572^{b, c}$ & $15.42^{b, c}$ \\
\hline Fringe 1 & $29.0^{b, c}$ & $6.06^{\mathrm{c}}$ & $0.11^{\mathrm{b}}$ & $0.04^{a, b}$ & $556^{\mathrm{a}, \mathrm{b}}$ & $15.32^{b}$ \\
\hline Fringe 2 & $29.1^{c}$ & $6.13^{c}$ & $0.08^{a}$ & $0.03^{a}$ & $558^{a, b, c}$ & $15.43^{b, c}$ \\
\hline Glacis & $28.1^{\mathrm{a}}$ & $5.70^{\mathrm{a}}$ & $0.22 \mathrm{e}$ & $0.12^{c}$ & $544^{\mathrm{a}}$ & $14.66^{\mathrm{a}}$ \\
\hline Valley bottom & $28.7^{b}$ & $6.12^{c}$ & $0.28^{f}$ & $0.38^{\mathrm{d}}$ & $574^{c}$ & $15.71^{\mathrm{c}, \mathrm{d}}$ \\
\hline SED (main site effects) & 0.4 & 0.1 & 0.02 & 0.04 & 16 & 0.27 \\
\hline \multicolumn{7}{|l|}{ Depth (D) } \\
\hline $3 \mathrm{~cm}$ & $29.0^{\mathrm{c}}$ & $5.94^{\mathrm{a}}$ & $0.17^{\mathrm{a}}$ & $0.12^{\mathrm{a}}$ & $550^{a}$ & $15.12^{\mathrm{a}}$ \\
\hline $8 \mathrm{~cm}$ & $28.5^{b}$ & $5.98^{a}$ & $0.19^{b}$ & $0.14^{a}$ & $564^{b}$ & $15.42^{b}$ \\
\hline $20 \mathrm{~cm}$ & $28.4^{\mathrm{a}}$ & $5.98^{a}$ & $0.20^{\mathrm{c}}$ & $0.18^{b}$ & $566^{b}$ & $15.44^{\mathrm{b}}$ \\
\hline $35 \mathrm{~cm}$ & $29.0^{\mathrm{c}}$ & $5.99^{\mathrm{a}}$ & $0.23^{d}$ & $0.29^{c}$ & $569^{b}$ & $15.47^{b}$ \\
\hline SED (main depths effects) & 0.2 & ns & 0.01 & 0.03 & 10 & 0.2 \\
\hline Source of Variance & \multicolumn{6}{|c|}{$p$-Value } \\
\hline Year $(Y)$ & $<0.001$ & 0.06 & $<0.001$ & $<0.001$ & 0.40 & 0.63 \\
\hline Site (S) & $<0.001$ & $<0.001$ & $<0.001$ & $<0.001$ & $<0.001$ & $<0.001$ \\
\hline Depth (D) & $<0.001$ & 0.45 & $<0.001$ & $<0.001$ & 0.03 & 0.01 \\
\hline $\mathrm{Y} \times \mathrm{S}$ & $<0.001$ & 0.04 & 0.69 & 0.85 & 0.41 & 0.12 \\
\hline $\mathrm{Y} \times \mathrm{D}$ & 0.49 & 0.86 & 0.37 & 0.02 & $<0.001$ & $<0.001$ \\
\hline $\mathrm{S} \times \mathrm{D}$ & 0.99 & 0.77 & 0.95 & 0.99 & 0.91 & 0.94 \\
\hline $\mathrm{Y} \times \mathrm{S} \times \mathrm{D}$ & 0.99 & 0.05 & 0.05 & $<0.001$ & 0.03 & 0.03 \\
\hline
\end{tabular}

ECb: bulk electrical conductivity; Eh: soil redox potential; $\mathrm{pH}$ : soil $\mathrm{pH} ; \mathrm{Pe}+\mathrm{pH}$ : soil pe $+\mathrm{pH}$. SED: standard error of a difference. $\mathrm{a}, \mathrm{b}, \mathrm{c}, \mathrm{d}, \mathrm{e}, \mathrm{f}$ - letters in a column within a set indicate significant difference at $p<0.05$ by the least significant difference test. ns: not significant. 


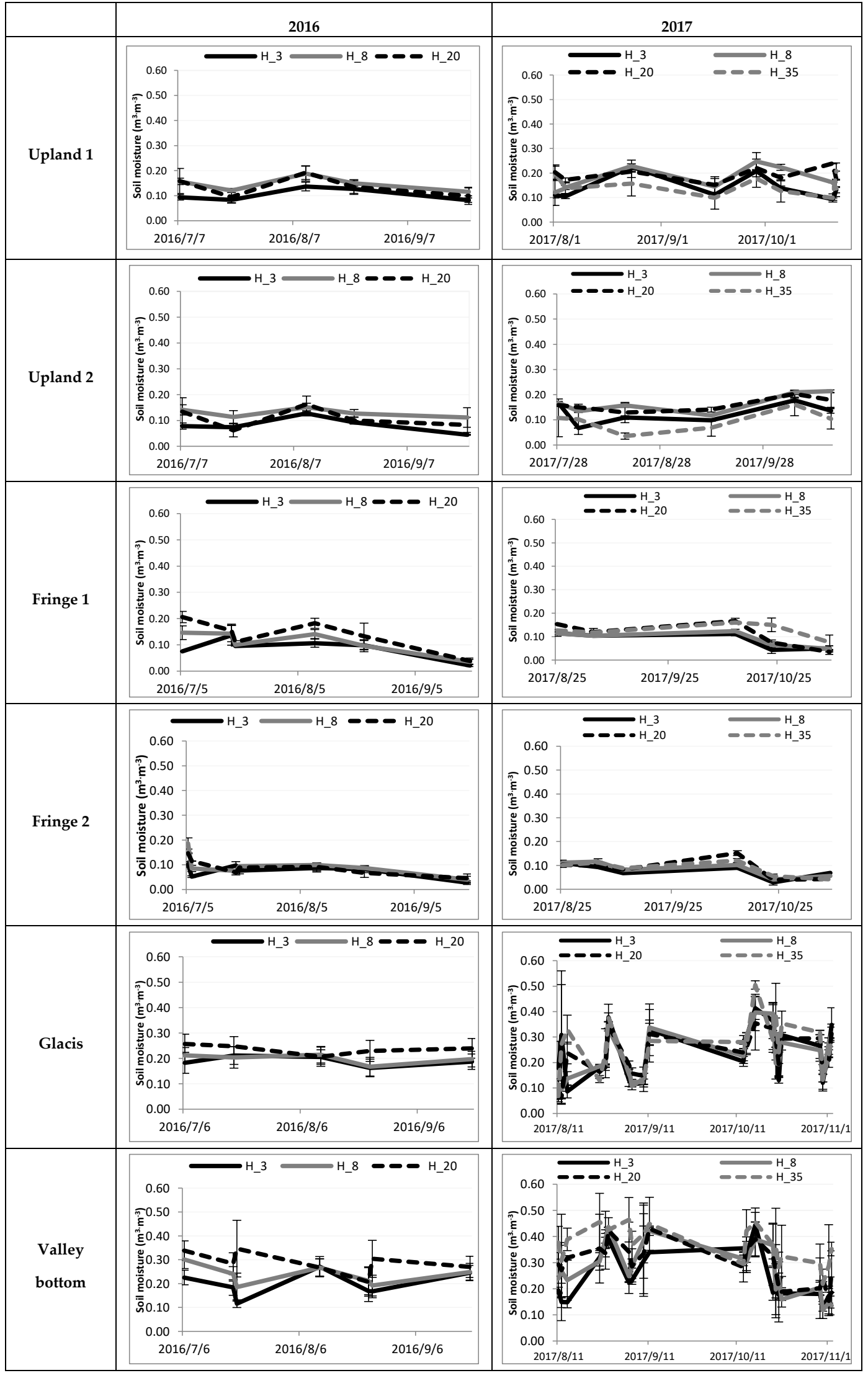

Figure 5. Soil moisture at different soil depths during the 2016 and 2017 growing seasons. Error bars indicate the standard errors of the mean. 


\subsection{Soil Temperature Variation}

Soil temperature varied greatly, depending on the year of the experiment, the location of the site and the depth of the soil (Figure S2). On average, soil temperature was higher in $2017\left(29.1^{\circ} \mathrm{C}\right)$ than in $2016\left(28.2^{\circ} \mathrm{C}\right)$. The greatest amplitudes of temperature variation were recorded at Upland 2, between $23.5^{\circ} \mathrm{C}$ and $37^{\circ} \mathrm{C}$ in 2016 , and at Fringe 1 , between $25.8^{\circ} \mathrm{C}$ and $35.1^{\circ} \mathrm{C}$ in 2017 . The smallest amplitudes were registered at the glacis, between $25.5^{\circ} \mathrm{C}$ and $31^{\circ} \mathrm{C}$ in 2016 , and at the valley bottom, between $25.1{ }^{\circ} \mathrm{C}$ and $32.8^{\circ} \mathrm{C}$ in 2017 . The lowest average temperature was recorded at the glacis, $28.1^{\circ} \mathrm{C}$, and the mean highest temperature was recorded in Upland $1\left(29.5^{\circ} \mathrm{C}\right)$.

There was also a significant year-by-site interaction effect on soil temperature. In 2016, the lowest soil temperature was recorded at Upland $2\left(23.5^{\circ} \mathrm{C}\right)$, while in 2017 , the lowest soil temperature was found at the glacis $\left(25.1^{\circ} \mathrm{C}\right)$. On average, the soil temperature was higher at a $3 \mathrm{~cm}$ depth and decreased with soil depth (Table 2).

\subsection{Electrical Conductivity Variation}

The evolution of the bulk electrical conductivity $(\mathrm{Ecb})$ of soils is presented in Figure 6. The bulk electrical conductivity varied significantly with the location of the site. Conductivity was significantly higher in 2017 (Table 2). Lowland ecology recorded the highest averages $\left(0.38 \mathrm{mS}^{-\mathrm{cm}^{-1}}\right.$ and $0.12 \mathrm{mS} \mathrm{cm}^{-1}$, respectively, for valley bottom and glacis). The fringes recorded the lowest averages $\left(0.04 \mathrm{mS} . \mathrm{cm}^{-1}\right.$ and $0.03 \mathrm{mS} . \mathrm{cm}^{-1}$, respectively, for Fringe 1 and Fringe 2). On the upland, the averages of $0.09 \mathrm{mS} . \mathrm{cm}^{-1}$ and $0.06 \mathrm{mS} . \mathrm{cm}^{-1}$ were recorded for Upland 1 and Upland 2, respectively (Table 2). In the valley bottom where the highest Ecb was observed, there was a strong fluctuation, ranging

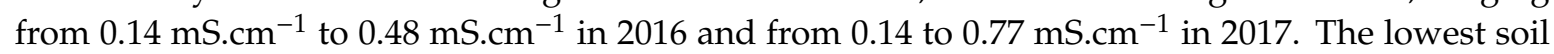
conductivity was at Fringe 2 and ranged from $0.01 \mathrm{mS} . \mathrm{cm}^{-1}$ to $0.1 \mathrm{mS} . \mathrm{cm}^{-1}$ in 2016 and $0.00 \mathrm{mS}^{-\mathrm{cm}^{-1}}$ to $0.05 \mathrm{mS} . \mathrm{cm}^{-1}$ in 2017. At all sites, the lowest conductivity was recorded at a depth of $3 \mathrm{~cm}$ with an average of $0.12 \mathrm{mS} . \mathrm{cm}^{-1}$; depths of $20 \mathrm{~cm}$ and $35 \mathrm{~cm}$ had the highest conductivity, with respective averages of $0.18 \mathrm{mS} . \mathrm{cm}^{-1}$ and $0.29 \mathrm{mS}^{-\mathrm{cm}^{-1}}$ (Figure 6).

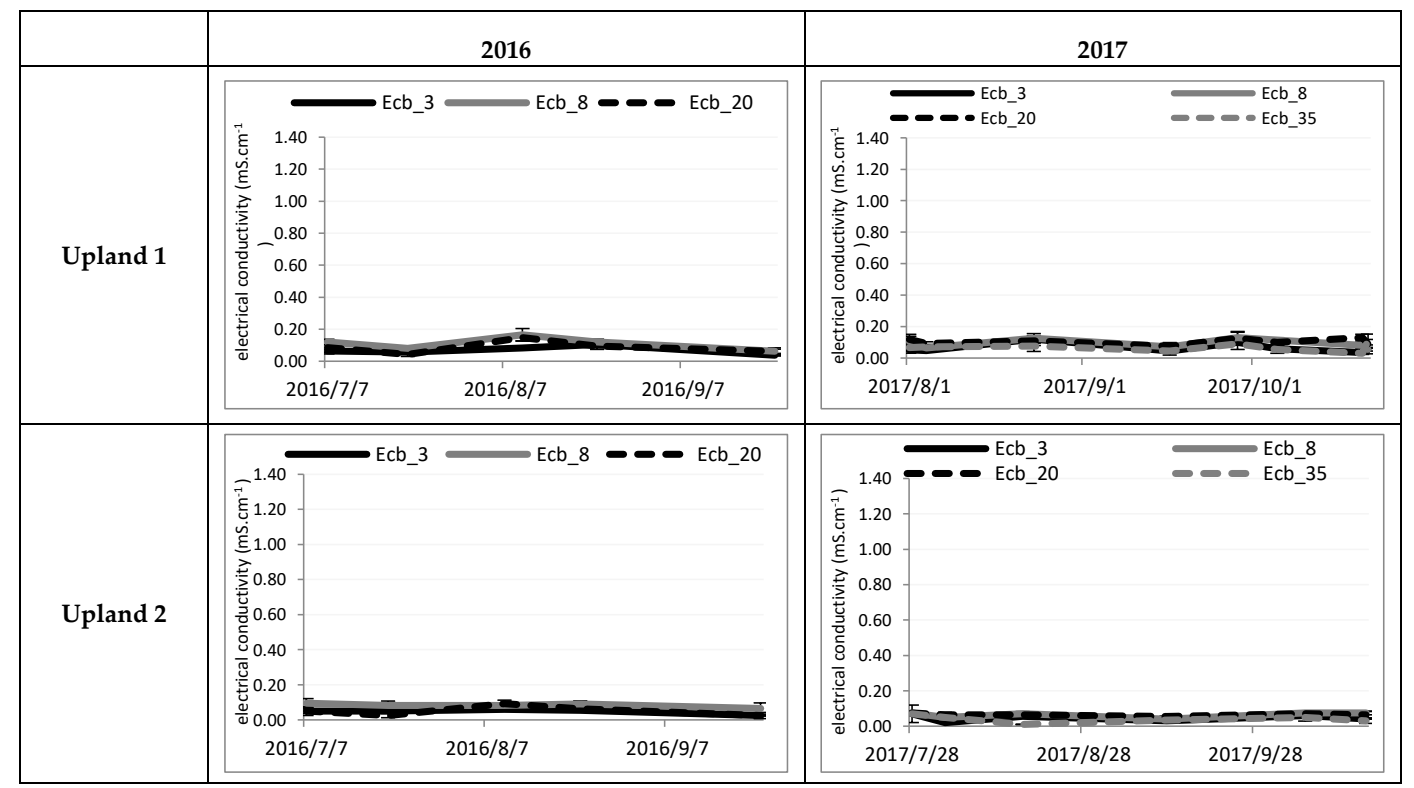

Figure 6. Cont. 


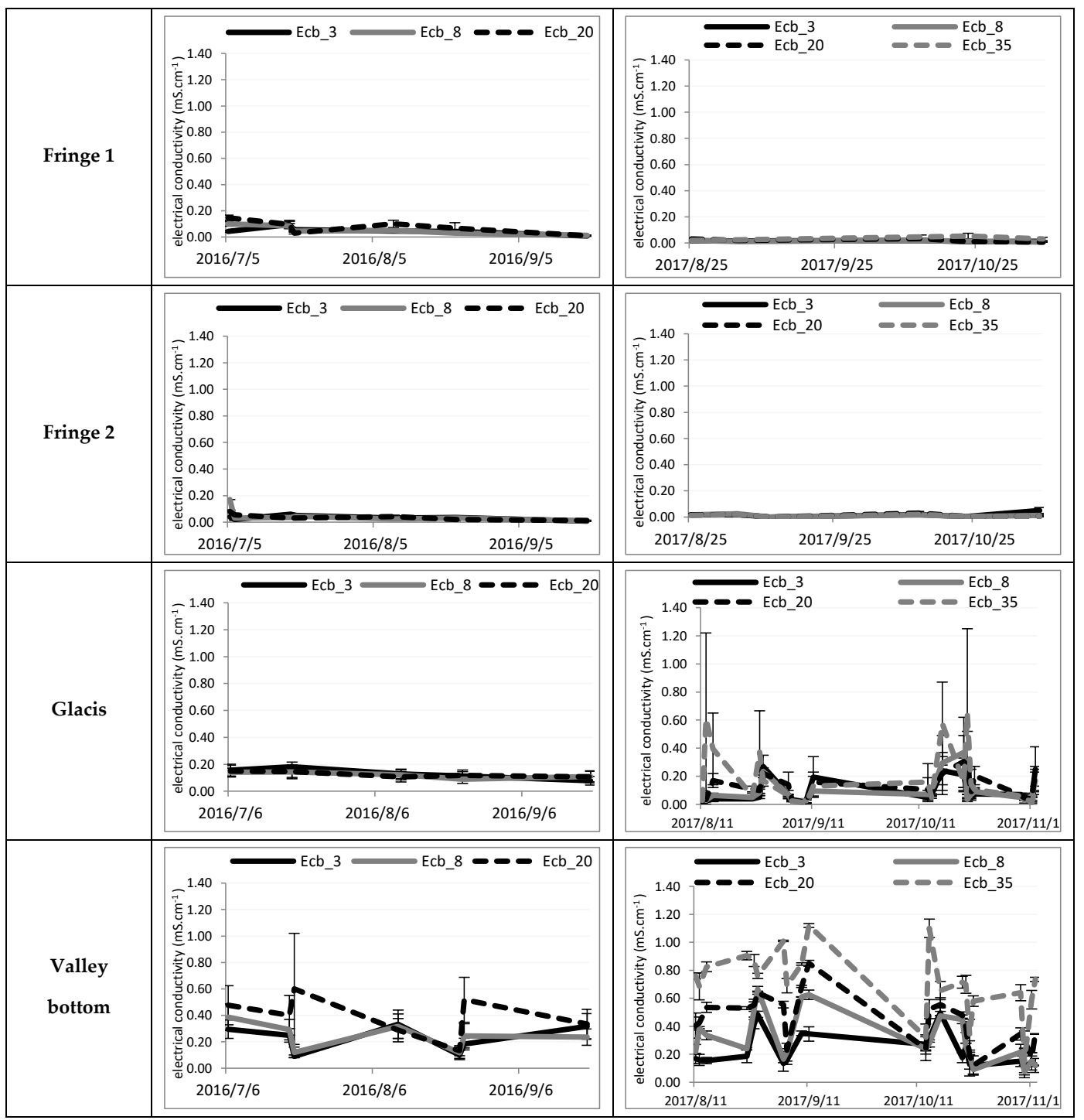

Figure 6. Soil bulk conductivity at different soil depths during the 2016 and 2017 growing seasons. Error bars indicate the standard errors of the mean.

\subsection{Soil pH Variation}

There was no significant year-by-site location interaction effect on soil $\mathrm{pH}$ (Table 2 and Figure 7). The lowest $\mathrm{pH}$ was observed at the glacis (5.70), followed by Upland 2 (5.90). The highest $\mathrm{pH}$ was observed at Upland 1 (6.40). The soils of Fringe 1, Fringe 2 and the valley bottom had a pH 6.06, 6.13 and 6.12 , respectively.

The smallest fluctuation amplitudes during the crop cycle were observed at Upland 1 ( 0.26 and 0.62, respectively, in 2016 and 2017) and then followed the fluctuation amplitudes observed in 2016 and 2017 on Fringe 1 (0.9 and 0.42), Upland 2 (1.07 and 0.96) and Fringe 2 (0.97 and 1.56). The highest fluctuation amplitudes were recorded in the lowland ecology on the glacis (1.2 and 1.91) and valley bottom (1.34 and 1.52) (Figure 7). 


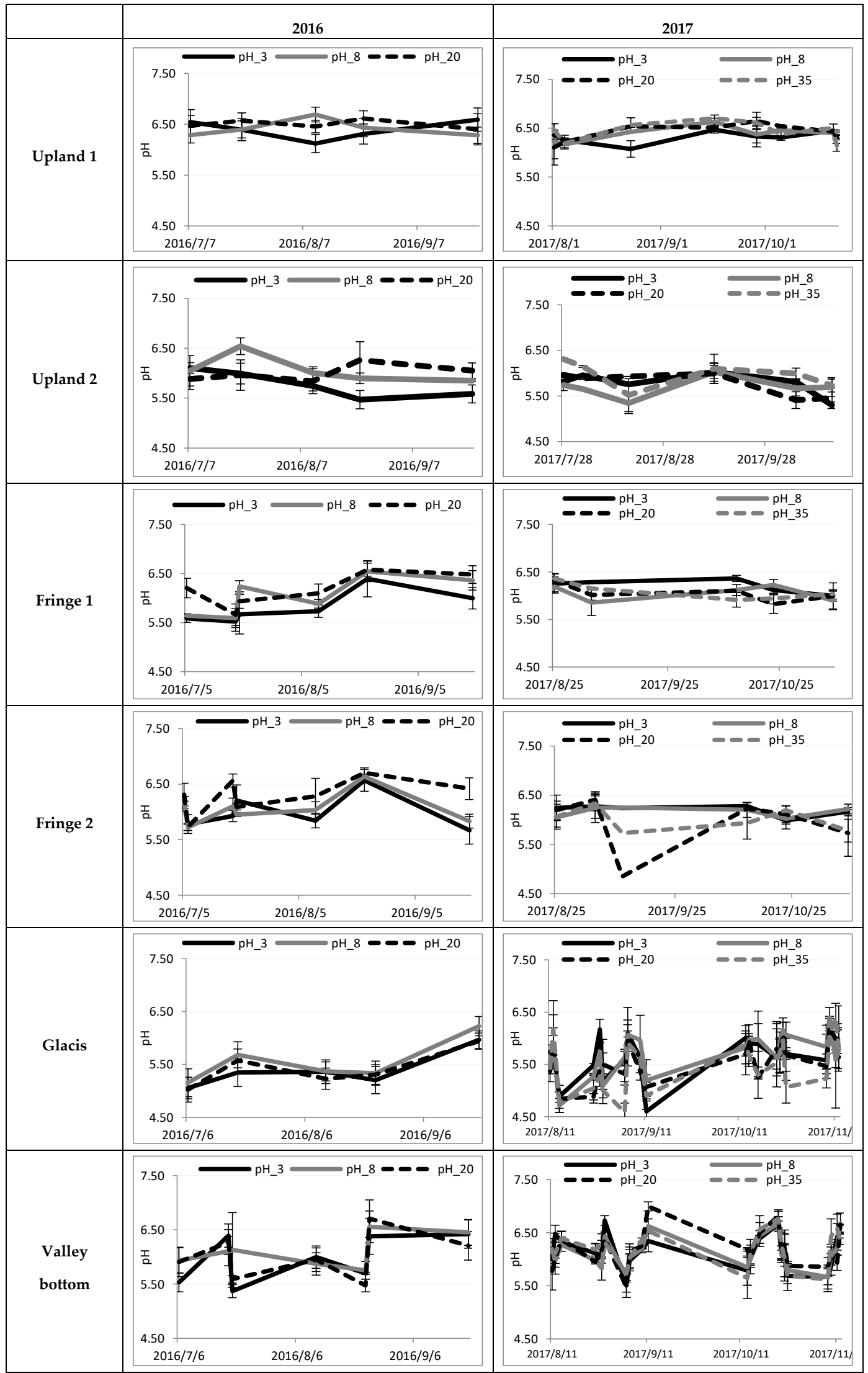

Figure 7. Soil pH at different soil depths during the 2016 and 2017 growing seasons. Error bars indicate the standard errors of the mean. 


\subsection{Soil Redox Potential Variation}

Figure 8 presents the ecological dynamics of the redox potential for the uplands (Upland 1 and Upland 2), fringes (Fringe 1 and Fringe 2) and lowlands (glacis and valley bottom) soils during the growing season (June to December) of the 2016 and 2017 seasons. It was observed that, at the beginning of each season, the soil redox potential was around $500 \mathrm{mV}$ before fluctuating during the growing season. This dynamic varied according to the site and the depth of the measurement. However, there was no significant difference between the average soil redox potential over the two years of study (Table 2).

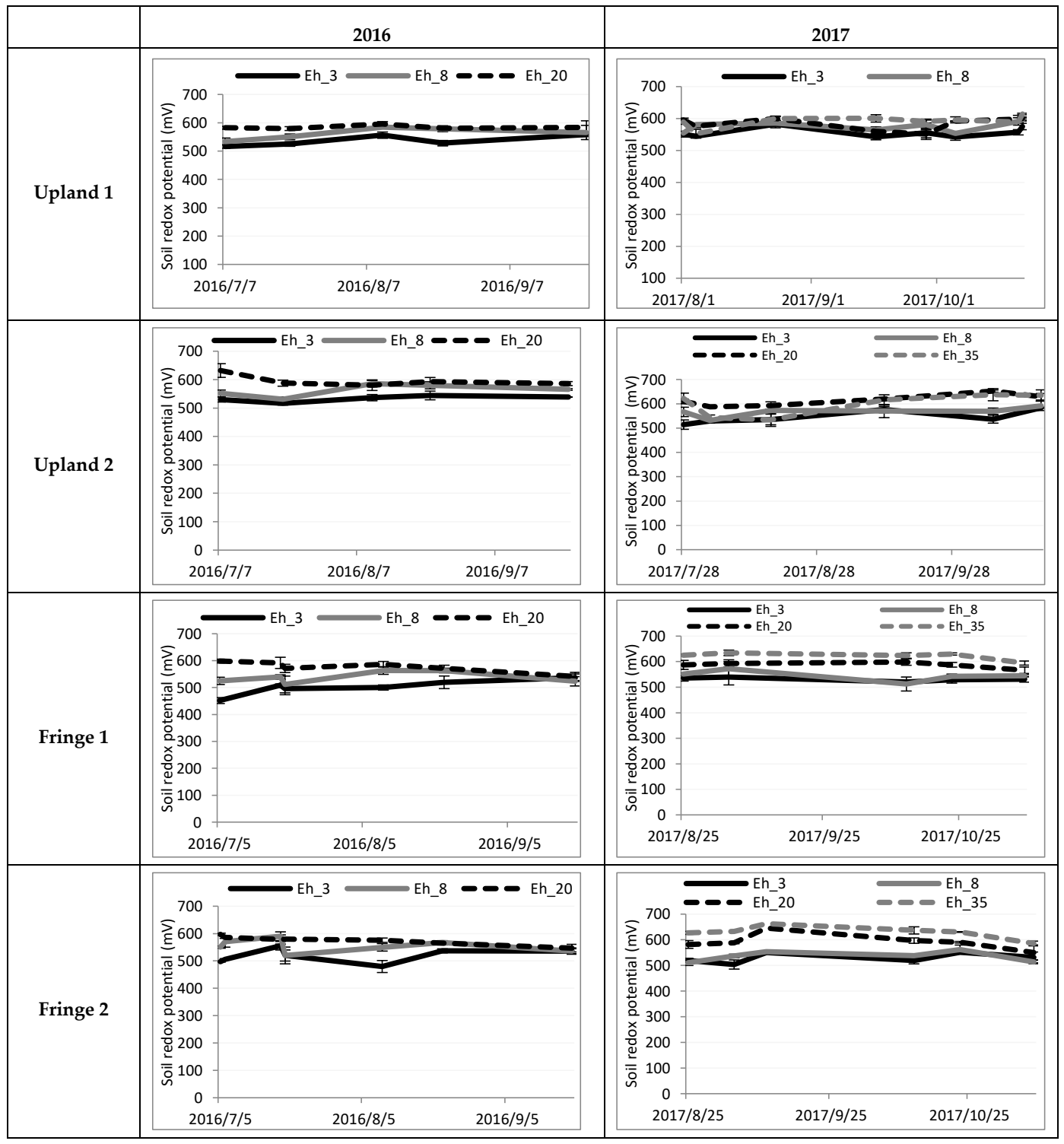

Figure 8. Cont. 


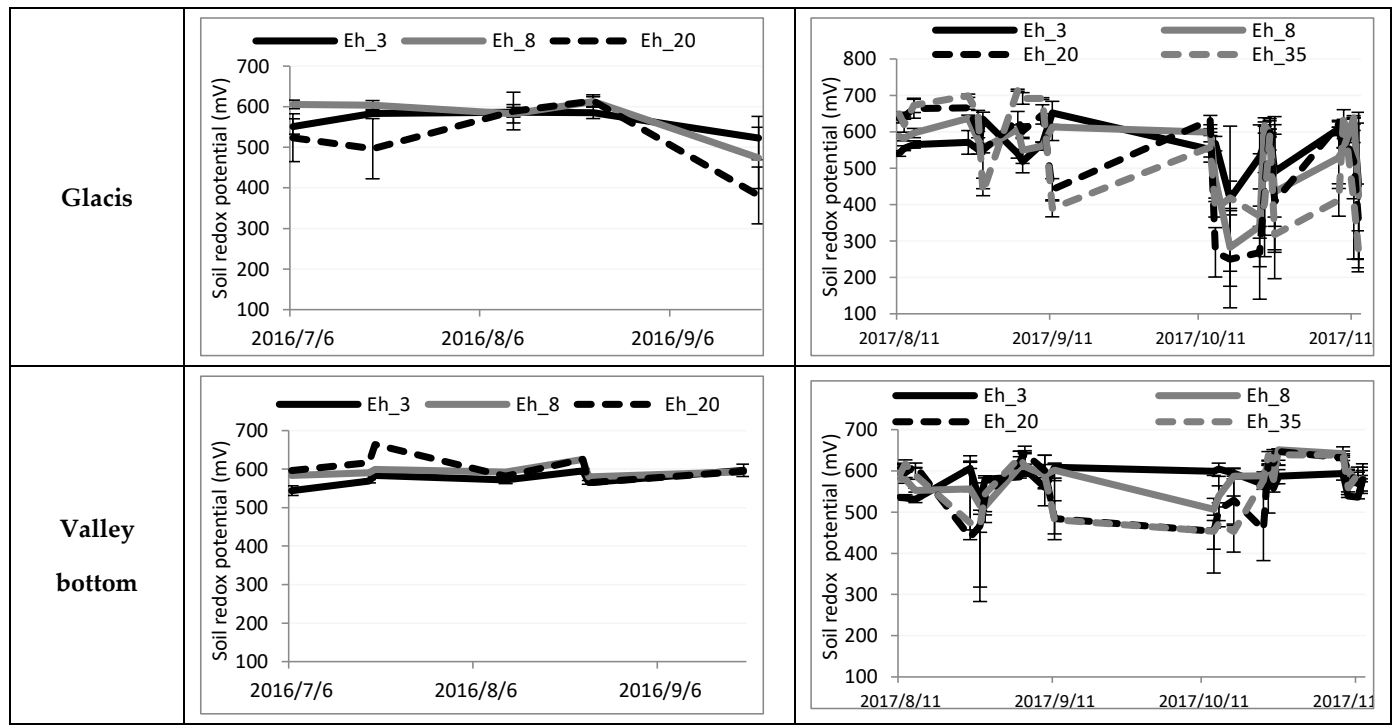

Figure 8. Soil redox potential at different soil depths during the 2016 and 2017 growing seasons. Error bars indicate the standard errors of the mean.

The mean Eh was significantly lower at the glacis $(544 \mathrm{mV})$ and the valley bottom had the highest Eh average ( $574 \mathrm{mV}$ ), followed by the uplands ( 570 and $572 \mathrm{mV}$ for Upland 1 and Upland 2, respectively) and fringe soils (556 and $558 \mathrm{mV}$ for Fringe 1 and Fringe 2, respectively).

During the 2016 growing season, the redox potential of the upland soils was more stable. The variations over the entire cycle remained in the range of 516 to $595 \mathrm{mV}$ (Upland 1) and 520 to $632 \mathrm{mV}$ (Upland 2) for the three depths of 3, 8 and $20 \mathrm{~cm}$. The lowest average redox potential was recorded at a depth $3 \mathrm{~cm}$ with mean values of 536 and $535 \mathrm{mV}$ for Upland 1 and Upland 2, respectively, and the redox variations at the fringe soils ranged from 479 to $591 \mathrm{mV}$ (Fringe 1) and from 464 to $591 \mathrm{mV}$ (Fringe 2). A depth of $3 \mathrm{~cm}$ recorded the lowest average redox, $504 \mathrm{mV}$ and $518 \mathrm{mV}$, respectively, for Fringe 1 and Fringe 2. At the lowland ecology, redox fluctuations in the soil were 544 and $628 \mathrm{mV}$ for the valley bottom and more pronounced for the glacis ( 381 to $614 \mathrm{mV}$ ), for depths of 3,8 and $20 \mathrm{mV}$ in 2016. A depth of $20 \mathrm{~cm}$ recorded the mean lowest redox potential $(521 \mathrm{mV})$ at the glacis.

In 2017, the upland soils remained relatively stable throughout the cycle, with the redox potential varying from 540 to $601 \mathrm{mV}$ and from 521 to $652 \mathrm{mV}$ for Upland 1 and Upland 2, respectively, over all the depths-3, 8, 20 and $35 \mathrm{~cm}$. On these soils, the lowest average redox potential was recorded at a depth of $3 \mathrm{~cm}$.

Redox potential in the fringe soils varied from 512 to $648 \mathrm{mV}$ and from 500 to $662 \mathrm{mV}$ for Fringe 1 and Fringe 2, respectively. A depth of $3 \mathrm{~cm}$ had the lowest redox average and its relatively small amplitude of variation was $23 \mathrm{mV}$ and $50 \mathrm{mV}$ for Fringe 1 and Fringe 2, respectively.

At the lowland soils, the redox potential was particularly subject to repeated variations influenced by the rainfall regime. The amplitude of the variations was large for the depths 3, 8, 20 and $35 \mathrm{~cm}$, with the redox potential varying from 249 to $714 \mathrm{mV}$ and from 466 to $639 \mathrm{mV}$ for the glacis and the valley bottom, respectively. In mid-October 2017, the redox potential of the 8 and $20 \mathrm{~cm}$ depths of the glacis dropped below $400 \mathrm{mV}$. The lowest redox potential was recorded at a depth of $20 \mathrm{~cm}: 250 \mathrm{mV}$.

During the growing season, the amplitudes of the redox potential variations of the studied depths were particularly high on glacis, with $235,355,416$ and $443 \mathrm{mV}$ for the respective depths of 3, 8, 20 and $35 \mathrm{~cm}$. On the valley bottom soils, the amplitudes were $82,145,207$ and $185 \mathrm{mV}$, respectively, for the depths $3,8,20$ and $30 \mathrm{~cm}$.

On the lowland ecology, the lowest mean redox potential levels were inversely recorded at a depth of $35 \mathrm{~cm}$ with $528 \mathrm{mV}$ and $557 \mathrm{mV}$, respectively, for the glacis and valley bottom (Figure 8). 


\subsection{Variation in Soil pe $+p H$}

The mean soil pe $+\mathrm{pH}$ remained stable over the two years of study (Table 2). Soil pe $+\mathrm{pH}$ was significantly lower on the glacis (14.66) and higher on Upland 1 (15.90). The pe $+\mathrm{pH}$ averages of the other sites were 15.32, 15.42. 15.43 and 15.71 for Fringe 1, Upland 2, Fringe 2 and valley bottom, respectively.

There was a lower fluctuation of soil pe $+\mathrm{pH}$ at the upland soils (1.48-1.36 in 2016 and 1.37-2.26 in 2017 for Upland 1 and Upland 2, respectively) followed by fluctuations observed on the fringe (1.78-1.9 in 2016 and 2.1-2.68 in 2017 for Fringe 1 and Fringe 2, respectively). Soils at the lowland ecology recorded the highest fluctuations (3.93-2.45 in 2016 and 7.62-3.71 in 2017, for glacis and the valley bottom, respectively) (Figure 9). The mean pe $+\mathrm{pH}$ was significantly lower at a depth of $3 \mathrm{~cm}$ (15.12) compared to the mean of the depths 8,20 and $35 \mathrm{~cm}$ with 15.42, 15.44 and 15.47, respectively (Figure 9).

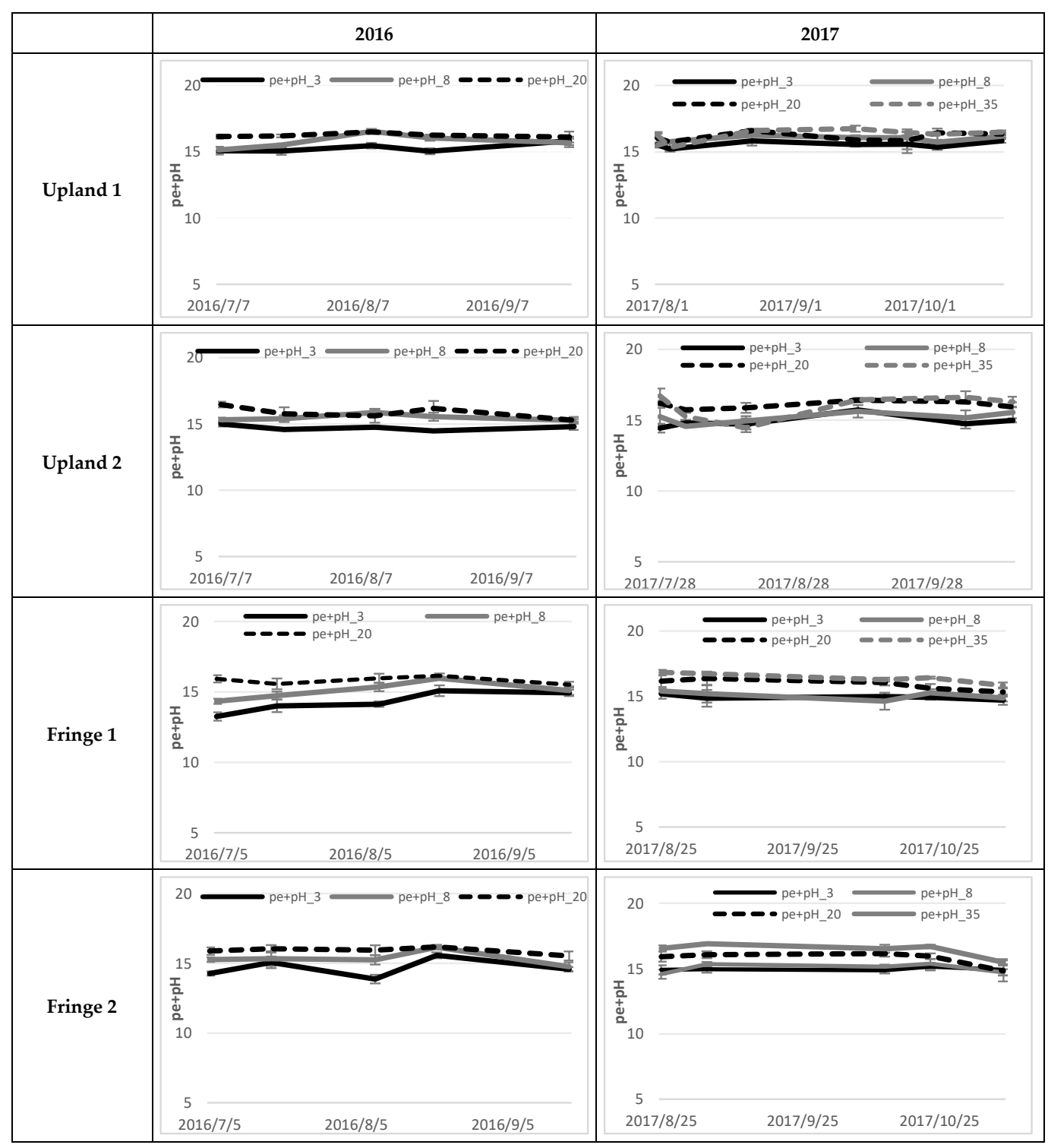

Figure 9. Cont. 


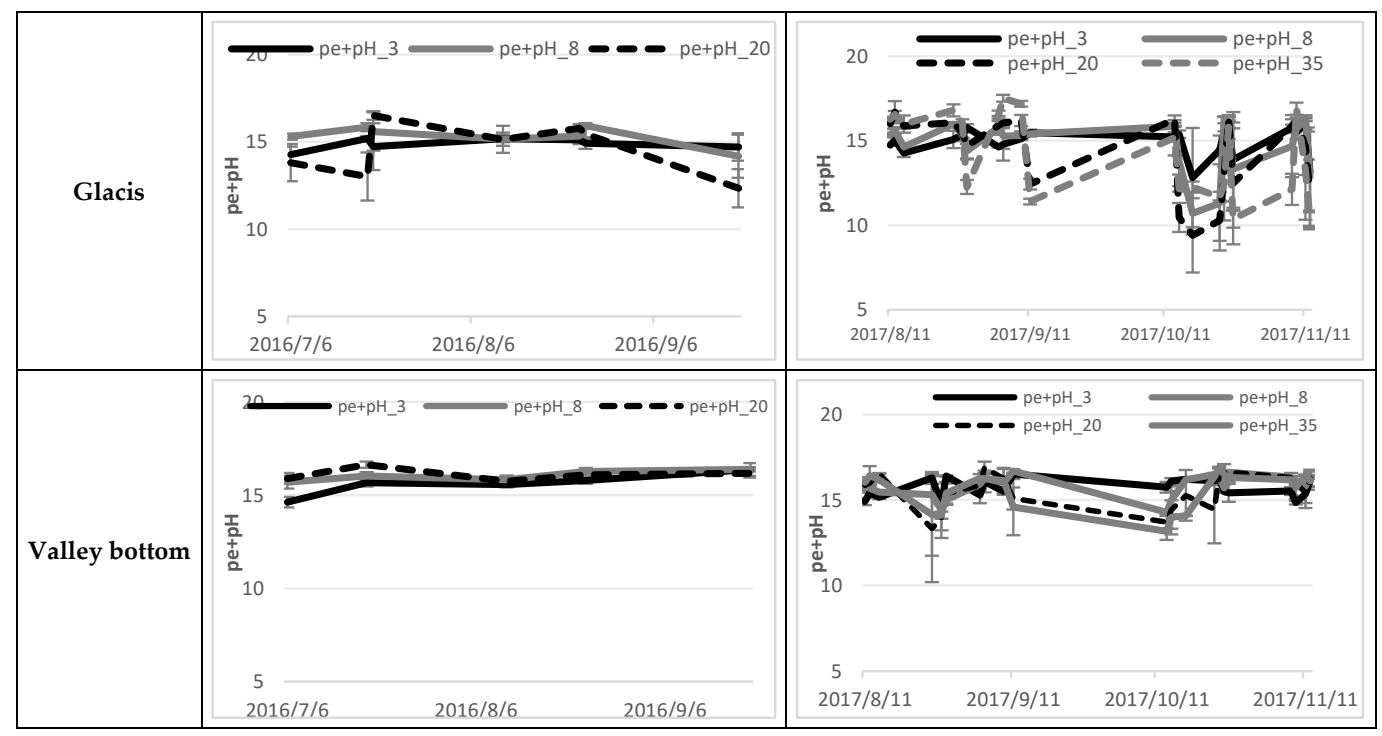

Figure 9. Soil pe $+\mathrm{pH}$ at different soil depths during the 2016 and 2017 growing seasons. Error bars indicate the standard errors of the mean.

\subsection{Relationships between Soil Potential Redox and Other Soil Electrochemical Properties}

Relationships between the soil electrochemical and water parameters were studied from the averages of the data collected at the measurement points on the different sites during the two growing seasons (Figure 10).

Figure 10a shows a two-phase effect of moisture on the soil redox potential. A phase of increase of the redox potential is observed, with the increase of the soil moisture at the depths $3 \mathrm{~cm}, 8 \mathrm{~cm}$ and $20 \mathrm{~cm}$ reaching a maximum of $0.20 \mathrm{~m}^{3} \cdot \mathrm{m}^{-3}$ soil moisture. Beyond this threshold value, a decay phase of Eh is observed over the three depths to reach values of $545-538 \mathrm{mV}$ at $0.30-0.36 \mathrm{~m}^{3} \cdot \mathrm{m}^{-3}$ of humidity. Quadratic functions to better reflect the effect of moisture, highlight a gradient of Eh between depths of $3 \mathrm{~cm}, 8 \mathrm{~cm}$ and $20 \mathrm{~cm}$. Significant $(<0.001)$ quadratic correlations were also established between Eh and the soil moisture content for each depth, with $\mathrm{R}^{2}$ correlation coefficients of $0.71,0.51$ and 0.54 , respectively, for depths of $3 \mathrm{~cm}, 8 \mathrm{~cm}$ and $20 \mathrm{~cm}$.

A strong and positive correlation $(p<0.001)$ exists independently of depths $(3 \mathrm{~cm}, 8 \mathrm{~cm}$ and $20 \mathrm{~cm})$ between moisture and bulk electrical conductivity (Ecb); the $R^{2}$ coefficients are between 0.93 and 0.97 (Figure 10b). As a result, an effect similar to that of moisture was observed between Ecb and Eh. A phase of increase of Eh with Ecb was observed, followed by a decay phase after $0.2 \mathrm{mS}^{-\mathrm{cm}^{-1}}$ (Figure 10c). A depth gradient $(3 \mathrm{~cm}, 8 \mathrm{~cm}$ and $20 \mathrm{~cm})$ of Eh was observed on each phase. The correlations are significant, and their coefficients are $0.79,0.46$ and 0.36 , respectively, for depths $3 \mathrm{~cm}, 8 \mathrm{~cm}$ and $20 \mathrm{~cm}$.

In addition, soil moisture content showed a positive and significant correlation at a depth of $3 \mathrm{~cm}$ with soil organic carbon (SOC) content $\left(R^{2}=0.68\right)$; consequently, at this depth a positive effect of the carbon level on Eh was observed with a significant correlation and a correlation coefficient $R^{2}$ of 0.61 (Figure 10d,e). Such correlations are not found at $20 \mathrm{~cm}$ depth. To find significant correlations, the soils must be considered separately according to upland, fringe and lowland ecologies (Figure S3).

Globally, correlations between Eh and $\mathrm{pH}$ are poor $\left(\mathrm{R}^{2}\right.$ of $0.11,0.11$ and 0.22 , respectively, for the depths $3 \mathrm{~cm}, 8 \mathrm{~cm}$ and $20 \mathrm{~cm}$, observed in Figure 10f) and not significant. However, considering the upland, fringe and lowland ecologies separately, stronger correlations are obtained (Figure S4). 


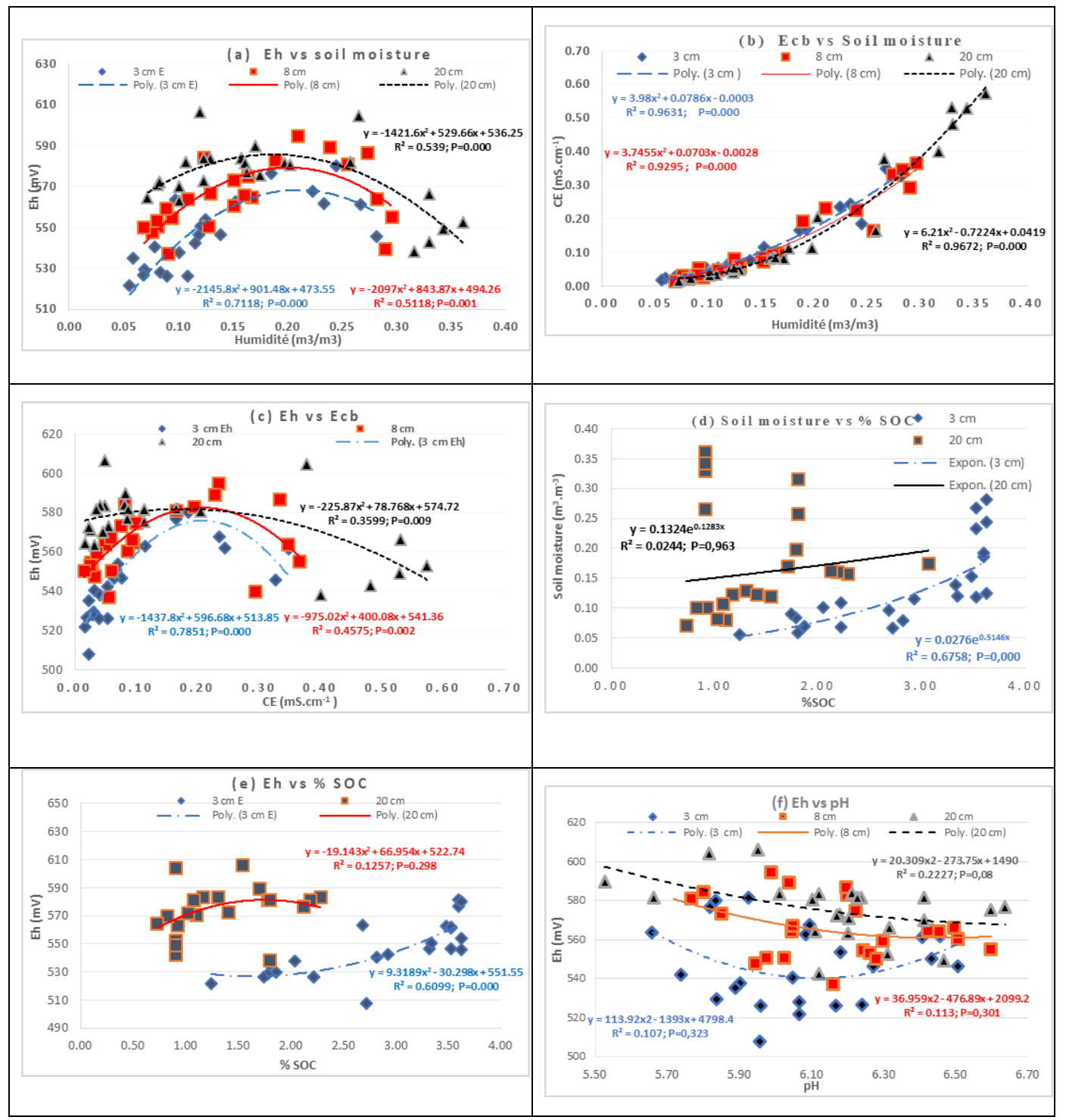

Figure 10. Relationship between soil moisture and Eh (a). Correlation of soil moisture and electrical conductivity and its consequence on Eh. (b,c) Effect of soil organic carbon (SOC) on soil moisture and its consequence on $\mathrm{Eh}(\mathbf{d}, \mathbf{e})$. Relationship between $\mathrm{pH}$ and $\mathrm{Eh}(\mathbf{f})$. The regression equations and correlation coefficients ( $\mathrm{R}^{2}$ and $p$ values) are determined for each depth.

\section{Discussion}

Similar redox potentials were observed for the two seasons of the study. The average redox potential was significantly different from one soil type to another and the standard errors at a given day and in a given site were rather low. This tends to confirm the reliability of the method of measurement of soil redox potential.

For all sites, soil Eh ranged from 106 to $717 \mathrm{mV}$. These values are in the fluctuation range of the soil redox values of -300 to $+900 \mathrm{mV}$ given in the literature [5,27]. Soil $\mathrm{pH}$ measured directly in field conditions was most of the time lower than the soil $\mathrm{pH}$ measured in laboratory conditions in a water extract $(1: 2.5 \mathrm{v} / \mathrm{v})$. As for Eh, $\mathrm{pH}$ showed great variation in time, especially in 2017 in the lower part of the toposequence (glacis and valley bottom), where the soil $\mathrm{pH}$ could vary by more than 1.5 units within a few weeks. Similarly, ECb greatly varied, increasing with soil moisture.

Globally, these results confirm the key role of soil moisture in soil functioning, as it is central to the dynamics and relationships between soil electrochemical parameters. 
In our study area and conditions, soil Eh variability could be mainly attributed to humidity, with a quadratic relationship between soil moisture and soil Eh. The raise in Eh with the raise in humidity in dry conditions reveals the chemical functioning of a soil with poor biological activity: low redox potential in dry soils are attributed to the loss of colloidal water that retains oxygen, and thus the loss of oxygen in a purely chemical process [15]. In a biologically active soil, the raise in soil moisture would favor the development of microorganisms, which consume oxygen and, as a consequence, would lower the Eh [28,29]. Although microbial activity has not been measured in this study, a low biological activity can be expected in these soils due to the frequent fires they endure and the cropping practices with soil tillage.

In all cases, with increasing water content, when the soil reaches saturation, the very slow diffusion of oxygen in water makes that soil Eh drop rapidly [18].

Surprisingly, the correlation between soil C content and Eh was positive, when soil C is often regarded as the electron reservoir [30], and thus a higher $C$ content is expected to have a lower soil Eh. This suggests that most of the $C$ was under a very stable form, not accessible to microbes and, as a consequence, a raise in total $\mathrm{C}$ content does not correspond to the expected raise in biological activity, which would lower the Eh [31]. Again, the hypothesis that most $C$ in these soils is under a very stable form is supported by the frequent fires in the study area, known to produce very stable black C [32,33]. Thus, the limitation of the available nutrients for microbes probably limits biological activity, which could be expected when soil moisture increases. As a consequence, the increase in soil moisture (Figure 10e) does not lead to an increase in soil biological activity sufficient to compensate for the chemical increase in Eh due to a higher water content. Better than total organic matter, it is the bioavailable organic matter, the part of the organic matter accessible to microorganisms, which actually constitutes the main reservoir of electrons [34].

This general framework can explain the variations in Eh, depending on the soil type/location on the toposequence:

(i) In the upland ecology (Upland 1 and Upland 2), the average redox potential was high $(570 \mathrm{mV}$ and $572 \mathrm{mV}$ for Upland 1 and Upland 2, respectively). Eh always remained above $500 \mathrm{mV}$ and the amplitude of variation remained very low for all the soil depths, particularly at a depth of $3 \mathrm{~cm}$. The low variation in soil Eh can be related to the rather high organic $C$ content of these soils, and probably the high content of stable, black $\mathrm{C}$ related to frequent fires. Biochar is known to have a high poising capacity for Eh [32,33]. Again, this supports the assumption that these soils have a low biological activity, and that most of their $C$ is stable $C$. This $C$ and the soil texture retain water, thus increasing soil moisture, while biological activity remains low. The Eh functioning of these soils is mainly related to soil chemistry, with high Eh related to soil moisture.

(ii) At the fringe, the redox potential always remained higher than $400 \mathrm{mV}$ for all soil depths. This indicates that the soil of the fringe has remained well drained [18]. The lower mean redox potential ( $556 \mathrm{mV}$ for Fringe 1 and $558 \mathrm{mV}$ for Fringe 2) as compared to upland conditions might be explained by the lower soil moisture, related to lower total soil $\mathrm{C}$. The higher fluctuations in redox potential (as compared to upland soils) may be explained by the lower soil C content, as $\mathrm{C}$, especially black $C$, is known to poise the redox potential.

(iii) The glacis had the lowest mean $\mathrm{Eh}(544 \mathrm{mV})$ and the highest amplitude in fluctuations, varying from 250 to $714 \mathrm{mV}$ for depths 3, 8, 20 and $35 \mathrm{~cm}$ all together. These large amplitudes on glacis can be explained by soil heterogeneity due, on the one hand, to its transitional position between the dry soils, upstream, and on the fringe and the wet soils, downstream. However, first of all, these large amplitudes in Eh on the glacis can be explained by local resurgences of water at this level in relation to a clayey layer. These resurgences of water led to temporary waterlogging, and therefore a strong decrease in soil Eh during the periods of water saturation: in water-saturated soils, oxygen diffusion is very slow, and dissolved oxygen is quickly consumed by soil organisms and plant roots; the soil would then have become anaerobic, as reported by [35], and these reduced conditions would cause a rapid fall in the redox potential. Similar observations have 
been made by $[18,35,36]$. Drainage that occurred a few days after the rain resulted in an increase in soil oxidation, as was also observed by [37]. Declines in the level of soil redox potential were particularly pronounced in mid-October, passing below $400 \mathrm{mV}$ before rising above $500 \mathrm{mV}$. The reduction of the redox potential was very pronounced at the lower depths, with the lowest soil redox potential recorded at a depth of $20 \mathrm{~cm}(285 \mathrm{mV})$.

(iv) Surprisingly, the valley bottom recorded the highest mean redox potential, ranging from 466 to $639 \mathrm{mV}$, with the highest average redox potential $(574 \mathrm{mV})$ of all sites. This may be explained by the fact that although it is located lower on the toposequence than the glacis, there was no observed flooding of the valley bottoms, even when the glacis was saturated with water from local resurgences. As a consequence, the high soil moisture in a soil rich in organic matter (especially black C), without water saturation, may explain the highest mean redox potential measured in the valley bottoms. The stronger ECb in the wettest parts might also contribute to raise the redox potential, which would also contribute to the higher Eh in the valley bottoms as compared to upland conditions.

Furthermore, the $\mathrm{pH}$ generally showed a negative correlation with redox potential, although the observed correlations were low. This can be partly attributed to the variability between sites because better correlations were observed within sites and in particular in the valley bottom.

Variations in pe+pH were low as compared to variations in Eh or $\mathrm{pH}$ alone; this parameter being mainly impacted by soil saturation in the glacis and to a lower extent in the valley bottoms.

Finally, it can be hypothesized that the differences in natural vegetation observed before land reclamation were at least partially related to differences in soil electrochemical conditions, as already observed by [38].

\section{Conclusions}

This study evaluated the spatial and temporal variation in soil redox potential at different positions along the upland-lowland continuum during two growing seasons. Soil redox potential was above $500 \mathrm{mV}$ at the upland positions, between 400 and $700 \mathrm{mV}$ at the fringe positions and between 100 and $750 \mathrm{mV}$ at the lowland positions. Variation in soil redox potential was driven by soil moisture, bulk electrical conductivity and soil organic carbon. The results presented here have several implications for further studies:

Firstly, regarding the protocols for measurement of soil electrochemical parameters: in order to take into account the soil moisture content at the moment of the measurement, it should be systematically measured together with soil Eh, $\mathrm{pH}$ and EC.

Secondly, regarding soil carbon content: there is an urgent need to consider not only the total carbon content, but also the carbon easily accessible to microbes as it strongly impacts soil biological activity, which is a major factor regulating soil Eh. Thus, the form of soil carbon should be assessed in future studies dealing with soil electrochemical properties.

Thirdly, regarding the best parameter to assess the soil oxidation-reduction level: The use of $\mathrm{pe}+\mathrm{pH}$, which showed lower variability in space and time than Eh or $\mathrm{pH}$ alone, could be a good indicator of soil electrochemical conditions.

Finally, although it shows that soil Eh-pH-EC can be accurately be measured with adapted protocols, this study clearly shows the very high spatial and temporal variability of soil Eh, but also $\mathrm{pH}$ and ECb. The sensitivity of these parameters to other parameters, especially humidity, raises strong limitations for their use to assess soil health. Even if conducted in fixed conditions of humidity, temperature, etc., a single measurement will not capture their variations nor reflect the actual conditions during the cropping season. A major challenge is to relate these important parameters to the production processes and assess their impact on plant production. To achieve this, Eh-pH-EC should be measured on a very regular basis, with frequent measurements all over the cultivation period, and especially following rainfall events. Doing so would allow to study the elaboration of yield, relating all the yield components to the actual soil Eh-pH-EC conditions during the period of their elaboration. It would 
also provide information on the capacity of a soil to buffer soil Eh, $\mathrm{pH}$ and $\mathrm{EC}$ and thus limit their variation, which appears to be an important parameter related to soil health.

Supplementary Materials: The following are available online at http://www.mdpi.com/2073-4395/10/11/1787/s1, Figure S1. Spatial variability of: soil pH (S1.1), soil electrical conductivity (S1.2), soil carbon (S1.3), soil sand and clay (S1.4), Figure S2: Soil temperature at different soil depths during 2016 and 2017 growing seasons. Error bars indicate standard error of means, Figure S3. Relationship between organic carbon and humidity according to: upland ecologies (S3.1), Fringe ecologies (S3.2) and Lowland ecologies (S3.3), Figure S4. Relationship between pH and Eh according to: upland ecologies (S4.1), fringe ecologies (S4.2), lowland ecologies (S4.3).

Author Contributions: Conceptualization, O.H.; methodology, O.H. and B.F.T.; validation, K.F. and C.Y.B.; formal analysis, B.F.T., O.H. and E.R.D.-Y; investigation, O.H. and B.F.T.; resources, O.H. and K.S.; writing-original draft preparation, B.F.T.; writing-review and editing, O.H., C.Y.B., E.R.D.-Y. and K.S.; supervision, C.Y.B., M.C.S.W. and K.F.; funding acquisition, O.H. and K.S. All authors have read and agreed to the published version of the manuscript.

Funding: This research was funded by AfricaRice, the CGIAR Research Program on Rice and CIRAD.

Acknowledgments: The authors would like to thank the following AfricaRice staff members for their technical assistance: M. Kouame Etienne, experimental analyst, Ali Kouakou Ouattara, observer, and Goube Mairoua Salifou, head of the soil analysis laboratory.

Conflicts of Interest: The authors declare no conflict of interest.

\section{References}

1. Vanlauwe, B.; AbdelGadir, A.H.; Adewopo, J.; Adjei-Nsiah, S.; Ampadu-Boakye, T.; Asare, R.; Baijukya, F.; Baars, E.; Bekunda, M.; Coyne, D.; et al. Looking back and moving forward: 50 years of soil and soil fertility management research in sub-Saharan Africa. Int. J. Agric. Sustain. 2017, 15, 613-631. [CrossRef] [PubMed]

2. Depieu, E.M.; Doumbia, S.; Keli, J.Z.; Michel, Z. Typologie des exploitations en riziculture pluviale de la région de Saïoua, en zone forestière de la Côte d' Ivoire. J. Appl. Biosci. 2010, 35, 2260-2278.

3. Haefele, S.M.; Saito, K.; N’Diaye, K.M.; Mussgnug, F.; Nelson, A.; Wopereis, M.C.S. Increasing rice productivity through improved nutrient use in Africa. In Realizing Africa's Rice Promise; Wopereis, M.C.S., Johnson, D.E., Ahmadi, N., Tollens, E., Jalloh, A., Eds.; CAB International: Wallingford, UK, 2013; pp. 250-264.

4. Vlaar, J.C.J. Les Techniques de Conservations des Eaux et des Sols Dans les Pays du Sahel. 1992. Available online: https://www.ircwash.org/sites/default/files/276-92TE-11865.pdf (accessed on 26 September 2019).

5. Husson, $\mathrm{O}$. Redox potential (Eh) and $\mathrm{pH}$ as drivers of soil/plant/microorganism systems: A transdisciplinary overview pointing to integrative opportunities for agronomy. Plant Soil 2013, 362, 389-417. [CrossRef]

6. Arshad, M.A.; Martin, S. Identifying critical limits for soil quality indicators in agro-ecosystems. Agric. Ecosyst. Environ. 2002, 88, 153-160. [CrossRef]

7. Husson, O.; Audebert, A.; Benada, J.; Soglonou, B.; Tano, F.; Dieng, I.; Bousset, L.; Sarthou, J.-P.; Joseph, S.; Menozzi, P.; et al. Leaf EH and pH: A novel indicator of plant stress. Spatial, Temporal and Genotypic Variability in Rice (Oryza sativa L.). Agronomy 2018, 8, 209. [CrossRef]

8. Morel, L. Les Sols Cultivés, 2nd ed.; Ed. Tec \& Doc-Lavoisier: Paris, France, 1996.

9. Petruzzelli, G. Recycling wastes in agriculture: Heavy metal bioavailability. Agric. Ecosyst. Environ. 1989, 27, 493-503. [CrossRef]

10. Pigozzo, A.T.J.; Lenzi, E.; De Luca, J.; Scapim, C.A.; Da Costa, A.C.S. Transition metal rates in latosol twice treated with sewage sludge. Braz. Arch. Biol. Technol. 2006, 49, 515-526. [CrossRef]

11. Paillet, Y.; Cassagne, N.; Brun, J.J. Monitoring forest soil properties with electrical resistivity. Biol. Fertil. Soils 2010, 46, 451-460. [CrossRef]

12. Samouëlian, A.; Cousin, I.; Tabbagh, A.; Bruand, A.; Richard, G.; Samoue, A. Electrical resistivity survey in soil science: A review. Soil Tillage Res. 2005, 83, 173-193. [CrossRef]

13. Greenland, D.J.; Hayes, M.H. The Chemistry of Soil Processes; Greenland, D.J., Hayes, M.H.B., Eds.; Wiley: Chichester, PA, USA, 1981; Volume 7, pp. 295-296.

14. Snakin, V.V.; Prisyazhnaya, A.A.; Kovacs-Lang, E. Soil Liquid Phase Composition, 1st ed.; Elsvier: Amsterdam, The Netherlands, 2001; ISBN 0-444-50675-6. 
15. Husson, O.; Husson, B.; Brunet, A.; Babre, D.; Alary, K.; Sarthou, J.P.; Charpentier, H.; Durand, M.; Benada, J.; Henry, M. Practical improvements in soil redox potential (Eh) measurement for characterisation of soil properties. Application for comparison of conventional and conservation agriculture cropping systems. Anal. Chim. Acta 2016, 906, 98-109. [CrossRef]

16. Chesworth, W.; Cortizas, A.M.; Garc1, E. The redox-pH approach to the geochemistry of the Earth's land surface, with application to peatlands. Dev. Earth Surf. Process. 2006, 2025, 175-195.

17. Schwertmann, U.; Murad, E. Effect of $\mathrm{pH}$ on the formation of goethite and hematite from ferrihydrite. Clays Clay Miner. 1983, 31, 277-284. [CrossRef]

18. Ponnamperuma, F.N. The chemistry of submerged soils. In Advances in Agronomy; Academic Press: Cambridge, MA, USA, 1972; Volume 24, pp. 29-96.

19. Hall, S.J.; Mcdowell, W.H.; Silver, W.L. When Wet Gets Wetter: Decoupling of Moisture, Redox Biogeochemistry, and Greenhouse Gas Fluxes in a Humid Tropical Forest Soil. Ecosystems 2013, 16, 576-589. [CrossRef]

20. Stumm, W.; Morgan, J.J. An introduction emphasizing chemical equilibria in natural waters. In Aquatic Chemistry; Wiley-Interscience: New York, NY, USA, 1981; pp. 282-285. ISBN 978-0-471-51185-4.

21. Szafranek-nakonieczna, A.; Stepniewska, Z. The influence of the aeration status (ODR, Eh) of peat soils on their ability to produce methane. Wetl. Ecol. Manag. 2015, 23, 665-676. [CrossRef]

22. Diatta, S. Les Sols Gris de Bas Versant sur Granito-Gneiss en Région Centrale de la Côte d'Ivoire: Organisation Toposéquentielle et Spatiale, Fonctionnement Hydrologique: Conséquences Pour la Riziculture. Ph.D. Thesis, Université Henri Poincaré-Nancy 1, Nancy, France, 1996.

23. NF X31-107. Qualité du Sol-Détermination de la Distribution Granulométrique des Particules du Sol-Méthode à la Pipette; AFNOR: Paris, France, 2003.

24. Saito, K.; Asai, H.; Zhao, D.; Laborte, A.G.; Grenier, C. Progress in varietal improvement for increasing upland rice productivity in the tropics. Plant Prod. Sci. 2018, 21, 145-158. [CrossRef]

25. Pidello, A. Environmental redox potential and redox capacity concepts using a simple polarographic experiment. J. Chem. Educ. 2003, 80, 68-70. [CrossRef]

26. Lindsay, W.L.; Sadiq, M. Use of pe+pH to predict and interpret metal solubility relationships in soils. Sci. Total Environ. 1983, 28, 169-178. [CrossRef]

27. Patrick, W.H.J.; Mahapatra, I.C. Transformation and availability to rice plant of nitrogen and phosphorus in waterlogged soils. Adv. Agron. 1968, 20, 323-359.

28. Bohrerova, Z.; Stralkova, R.; Podesvova, J.; Bohrer, G.; Pokorny, E. The relationship between redox potential and nitrification under different sequences of crop rotations. Soil Tillage Res. 2004, 77, 25-33. [CrossRef]

29. Kralova, M. Redox Potential as an Indicator of Electron Availability for Microbial. Zentralbl. Mikrobiol. 1992, 147, 388-399. [CrossRef]

30. Chesworth, W. Redox, soil and carbon sequestration. Edafologia 2004, 11, 37-43.

31. Lovley, D.R.; Fraga, J.L.; Blunt-Harris, E.L.; Hayes, L.A.; Phillips, E.J.P.; Coates, J.D. Humic substances as a mediator for microbially catalyzed metal reduction. Acta Hydrochim. Hydrobiol. 1998, 26, 152-157. [CrossRef]

32. Joseph, S.; Husson, O.; Graber, E.R.; Van Zwieten, L.; Taherymoosavi, S.; Thomas, T.; Nielsen, S.; Ye, J.; Pan, G.; Chia, C.; et al. The electrochemical properties of biochars and how they affect soil redox properties and processes. Agronomy 2015, 5, 322-340. [CrossRef]

33. Klüpfel, L.; Keiluweit, M.; Kleber, M.; Sander, M.; Kluepfel, L.; Keiluweit, M.; Kleber, M.; Sander, M. Redox properties of plant biomass-derived black carbon (biochar). Environ. Sci. Technol. 2014, 48, 5601-5611. [CrossRef] [PubMed]

34. Chadwick, O.A.; Chorover, J. The chemistry of pedogenic thresholds. Geoderma 2001, 100, 321-353. [CrossRef]

35. Kyuma, K.P. Paddy Soil Science; Kyoto University Press: Kyoto, Japan, 2004; pp. 273-280. ISBN 1920901000.

36. Vizier, J.F. Etude de l'état d'oxydoréduction du sol et de ses conséquences sur la dynamique du fer dans les sols hydromorphes. Cah. ORSTOM 1971, 9, 373-397. 
37. Kongchum, M. Effect of Plant Residue and Water Management Practices on Soil Redox Chemistry, Methane Emission, and Rice Productivity. Ph.D. Thesis, Louisiana State University, Baton Rouge, LA, USA, 2005.

38. Pennington, M.R.; Walters, M.B. The response of planted trees to vegetation zonation and soil redox potential in created wetlands. Forest Ecol. Manag. 2006, 233, 1-10. [CrossRef]

Publisher's Note: MDPI stays neutral with regard to jurisdictional claims in published maps and institutional affiliations.

(C) 2020 by the authors. Licensee MDPI, Basel, Switzerland. This article is an open access article distributed under the terms and conditions of the Creative Commons Attribution (CC BY) license (http://creativecommons.org/licenses/by/4.0/). 